\title{
Steady-State Simulation of Steam Reforming of INEEL Tank Farm Waste
}

\author{
T. T. Nichols \\ D. D. Taylor \\ R. A. Wood \\ C. M. Barnes
}

August 2002

Idaho National Engineering and Environmental Laboratory Bechtel BWXT Idaho, LLC 


\title{
Steady-State Simulation of Steam Reforming of INEEL Tank Farm Waste
}

\author{
Todd T. Nichols \\ Dean D. Taylor \\ Richard A. Wood \\ Charles M. Barnes
}

\begin{abstract}
August 2002
Idaho National Engineering and Environmental Laboratory High Level Waste Program Idaho Falls, Idaho 83415
\end{abstract}

Prepared for the

U.S. Department of Energy

Assistant Secretary for Environmental Management

Under DOE Idaho Operations Office

Contract DE-AC07-99ID13727 


\begin{abstract}
A steady-state model of the Sodium-Bearing Waste steam reforming process at the Idaho National Engineering and Environmental Laboratory has been performed using the commercial ASPEN Plus process simulator. The preliminary process configuration and its representation in ASPEN are described. An assessment of the capability of the model to mechanistically predict product stream compositions was made, and fidelity gaps and opportunities for model enhancement were identified, resulting in the following conclusions: 1) Appreciable benefit is derived from using an activity coefficient model for electrolyte solution thermodynamics rather than assuming ideality (unity assumed for all activity coefficients). The concentrations of fifteen per cent of the species present in the primary output stream were changed by more than $50 \%$, relative to Electrolyte NRTL, when ideality was assumed; 2) The current baseline model provides a good start for estimating mass balances and performing integrated process optimization because it contains several key species, uses a mechanistic electrolyte thermodynamic model, and is based on a reasonable process configuration; and 3) Appreciable improvement to model fidelity can be realized by expanding the species list and the list of chemical and phase transformations. A path forward is proposed focusing on the use of an improved electrolyte thermodynamic property method, addition of chemical and phase transformations for key species currently absent from the model, and the combination of RGibbs and Flash blocks to simulate simultaneous phase and chemical equilibria in the off-gas treatment train.
\end{abstract}




\section{CONTENTS}

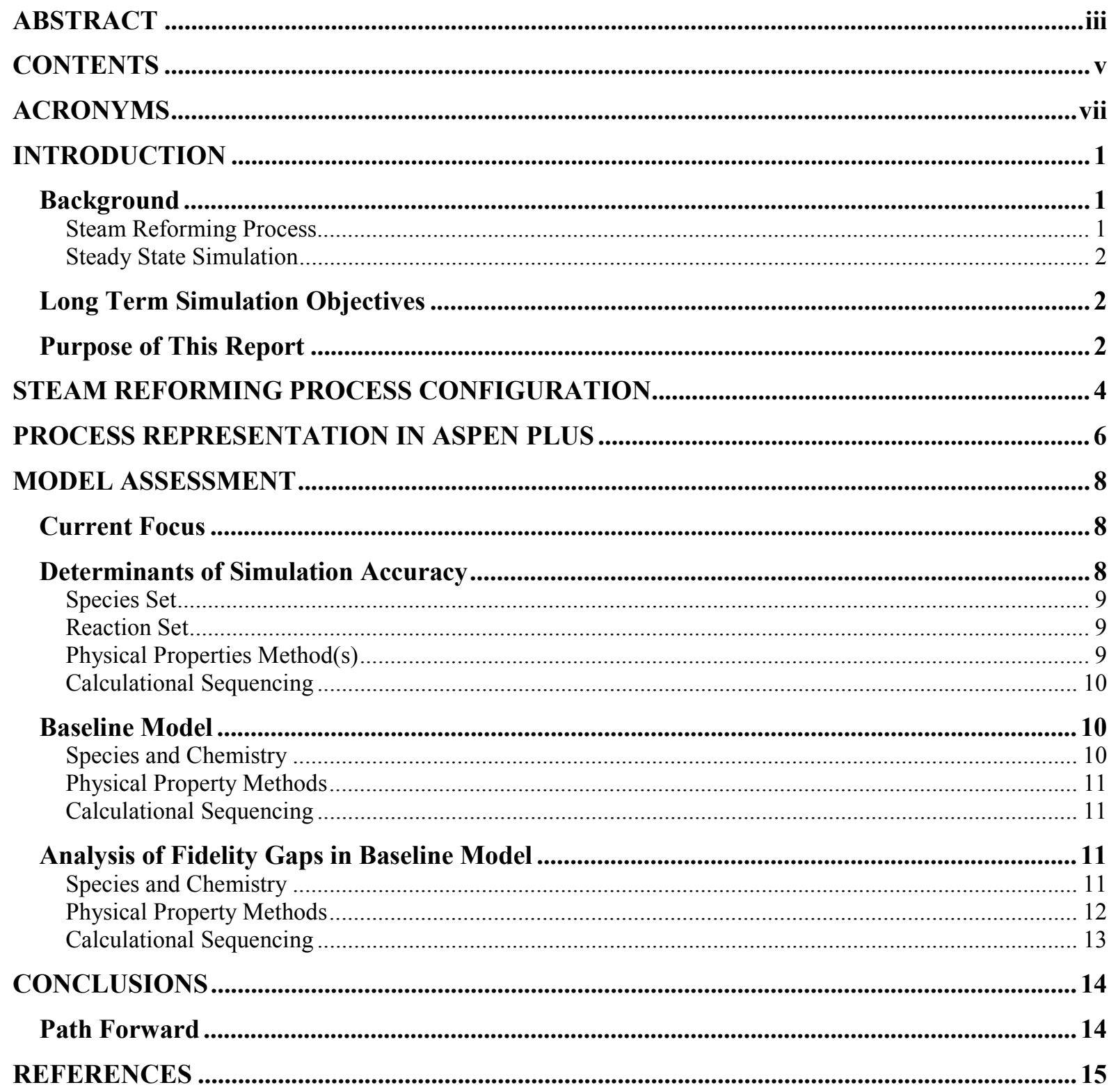

\section{FIGURES}

Figure 1. Original Steam Reforming Process Configuration........................................................................ 16

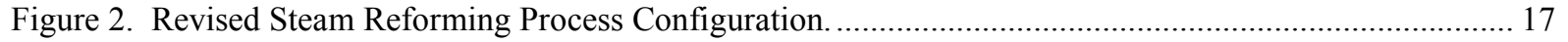

Figure 3. ASPEN Plus Process Flow Diagram........................................................................................ 18

\section{TABLES}

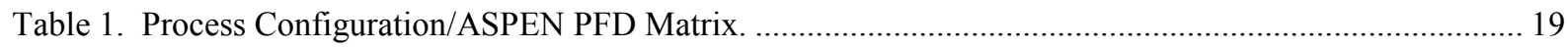

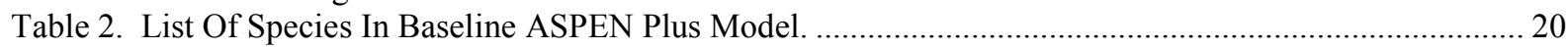

Table 3. List Of Reactions In Baseline ASPEN Plus Electrolyte Chemistry. ................................................... 22

Table 4. Species, Reactions, And Phase Transformations Needed For Simulation. .......................................... 23

Table 5. Thermodynamic Property Methods Currently Used By Unit Operation Blocks In ASPEN Plus Baseline

Simulation. 
Table 6. Comparison Of ENRTL And Ideal Property Methods (Summary).................................................... 28

Table 7. Comparison Between ENRTL And Ideal Property Methods (Complete Specie Data)......................... 29 


\section{ACRONYMS}

$\begin{array}{ll}\text { DOE } & \text { U.S. Department of Energy } \\ \text { GAC } & \text { Granular Activated Carbon } \\ \text { HEME } & \text { High-Efficiency Mist Eliminator } \\ \text { HEPA } & \text { High-Efficiency Particulate Air (filter) } \\ \text { HLLWE } & \text { High Level Liquid Waste Evaporator } \\ \text { HLW } & \text { High Level Waste } \\ \text { INEEL } & \text { Idaho National Engineering \& Environmental Laboratory } \\ \text { INTEC } & \text { Idaho Nuclear Technology \& Engineering Center } \\ \text { LET\&D } & \text { Liquid Effluent Treatment \& Disposal } \\ \text { MACT } & \text { Maximum Achievable Control Technology } \\ \text { NRTL } & \text { Non-Random Two Liquid } \\ \text { PEWE } & \text { Process Equipment Waste Evaporator } \\ \text { PFD } & \text { Process Flow Diagram } \\ \text { SBW } & \text { Sodium Bearing Waste } \\ \text { SL } & \text { Solid-Liquid (equilibrium) } \\ \text { TRU } & \text { Transuranic } \\ \text { TTP } & \text { Technical Task Plan } \\ \text { VL } & \text { Vapor-Liquid (equilibrium) } \\ \text { WIPP } & \text { Waste Isolation Pilot Plant }\end{array}$




\section{Steady-State Simulation of Steam Reforming of INEEL Tank Farm Waste}

\section{INTRODUCTION}

This report documents one phase of work in a larger, multi-year Tanks Focus Area-funded Technical Task Plan (TTP) project at the INEEL to develop an effective simulation tool to support high level waste (HLW) management. The scope of this effort has been documented elsewhere (Nichols et al, 2001a). Its current focus is on enhancement of previous simulation capability to support conceptual and detailed design of a SBW treatment process. Simulation capabilities are needed to support the entire synthesis/optimization life cycle from process configuration design to continuous improvement during operations. Specific application areas that are expected to benefit from availability of a high-fidelity simulation tool include: 1) Low-level unit operations modeling support for Tank Farm management; 2) Support for design of process control; 3) Process/cost optimization; 4) Emissions estimating for regulatory purposes; 5) Planning for trial burns;

6) Estimation of emissions that are physically unmeasurable on a continuous basis; and

7) Characterization of process variability for safety analysis.

\section{Steam Reforming Process}

\section{Background}

Steam reforming has been used extensively in industry for many years in a wide variety of applications. Only recently, however, has steam reforming been seriously considered for treatment of radioactive wastes. In July of 1999, a commercial steam reforming process was commissioned in Erwin, Tennessee to treat high activity (up to $100 \mathrm{R} / \mathrm{hr}$ beta/gamma) ion exchange resins produced by the nuclear power industry (Studsvik, 2000). Due to the success demonstrated at the Erwin facility, interest in steam reforming technology has increased in the DOE complex (Gentilucci, 2001). Steam reforming may be an economical method for treating liquid wastes currently stored at the INEEL and at other DOE sites.

In FY-2000, a brief steam reforming pilot-scale test was performed using a low activity INEEL waste simulant (Marshall \& Pao, 2000). Although not identical in composition to that expected for SBW, the acid, nitrate, and aluminum compositions in the simulant were comparable to anticipated SBW compositions for these constituents. Hence, results from this test may provide an indication of how steam reforming would perform if implemented for SBW treatment. Conclusions from this test were: 1) Steam reforming appears technically viable for effectively denitrating low-activity wastes containing primarily sodium, aluminum, and calcium nitrate salts, and 2) Gaseous effluent NOx can be controlled using reductants and metal-based additives.

More recently, steam reforming has been evaluated as a treatment option for low activity Hanford tank wastes. An initial pilot-scale test was performed in December 2001 (WGI, 2002). Conclusions from this test were: 1) The steam reforming process shows potential for converting low activity waste into a ceramic waste form suitable for disposal at Hanford, 2) Steam reforming can potentially reduce the period required to process all waste from the Hanford waste tanks (relative to the baseline low activity waste vitrification process), 3) Steam reforming can remove and destroy nitrates and organics present within the waste, and 4) A steam reforming process could potentially treat wastes that vary considerably in chemical composition. 


\section{Steady State Simulation}

The current steady-state simulation model of steam reforming of SBW using a commercial process simulation package includes the capability to perform rigorous thermodynamic equilibrium calculations. This capability was only available to a very limited extent in past efforts at process modeling to support high level waste program planning at the INEEL. At one point process mass balances used in planning and feasibility studies were performed with linked EXCEL spreadsheets which lacked a physical properties database. Later this process was automated using Visual Basic programs native to EXCEL. However, the modeling still lacked mechanistic predictive capability and was intended primarily to track feed components through process streams based on empirical or estimated partitioning data.

A major short-term objective of the TTP during FY-2002 has been to assemble a baseline steady state simulation of the integrated SBW steam reforming treatment process using the selected commercial software with its native thermodynamic database. This baseline simulation model has been used to provide "first estimate" type information in the following areas:

- Mass balance estimates focusing on stream sizes, composition and mass flow rates of waste product streams, and required input streams;

- Sizing information needed to assemble a preliminary equipment list and cost estimates;

- An integrated flowsheet with quantitative estimates of flow rates to stimulate and direct the thinking of process design personnel toward recommendations for improving subprocess efficiencies and robustness, reducing capital and operating costs, and minimizing the number and complexity of potentially problematic equipment.

\section{Long Term Simulation Objectives}

The current baseline model provides mostly empirically-based mass balance accounting which is needed at the current stage in the development of the SBW treatment flowsheet. Technically it represents no improvement (or only slight improvement) over the prior spreadsheet-based modeling approach. However, this baseline is a first and necessary step towards a longer-term objective to utilize (and possibly expand) the full thermodynamic predictive capability of the commercial process simulator. The steady-state baseline model utilizes a portion of that capability and provides a starting point to incrementally reduce the number of empirically-based submodels and correspondingly increase the number that are mechanistically-based.

\section{Purpose of This Report}

This report describes the current status of a steady-state model developed for steam reforming of INEEL SBW process using ASPEN Plus. The process configuration and its representation in ASPEN Plus are described. The principal objective in this effort is to supply the following types of information:

- Needed process mass and energy inputs

- Operational issues that may require attention in laying out the process

- Product stream compositions

For the current phase of the project the main focus has been on the third type of information and this report is similarly focused. An assessment of the capability of the model to predict product stream compositions is made, and fidelity gaps are identified. These gaps deal primarily with (a) the choice 
of the species that must be represented in the model, (b) the specification of the chemistry (set of possible reactions) that the model must account for, and (c) the selection of appropriate physical properties models to be used. From the identified fidelity gaps, opportunities for model enhancement are identified and a path forward is proposed. 


\section{STEAM REFORMING PROCESS CONFIGURATION}

A preliminary process configuration for steam reforming treatment of SBW was previously developed (Taylor et al., 2002) and is reproduced in Figure 1. After that configuration was developed and documented some minor changes were made before the configuration was modeled in ASPEN Plus. The revised configuration is shown in Figure 2. The changes to the original configuration and their rationale are described below.

- HEPA filter added upstream of thermal oxidizer. This operation is deemed necessary in order to (a) protect the oxidizer from particulate in the offgas that could present plugging and/or fouling problems (in the case of a catalytic unit), and (b) permit placement of the unit outside the hot cell. (The unit is quite large due to a large residence time requirement due to high water content of the input stream. In addition, it should be accessible for hands-on maintenance.)

- Condenser blowdown routed to caustic scrubber rather than to acid scrubber. This change reflects common operating practice to route contaminated fluids to the next higher area of contamination in order to minimize generation of contaminated streams. The condenser blowdown should be fairly clean and the caustic scrub liquor would likely be the next higher contaminated liquid in the offgas system.

- Condensate is not used for boiler feedwater. Condensate from the offgas will contain some radioactive contamination. The capital and operating expense associated with operating a contaminated boiler and feedwater system were deemed the overshadow the benefit of reduced water consumption through recycle of the condensate. Therefore consumptive use of uncontaminated water to supply steam to the reformer was used instead of condensate recycle.

- Liquid/solid separation for scrubber blowdown eliminated. The current assumption is that the steam reformed waste product will be packaged and disposed at WIPP. For this disposal option it was decided not to separate the high-activity reformer waste from the low-activity (and probably TRU-contaminated) salt waste. (This decision could be changed if higher disposal costs associated with higher volumes of remote-handled waste outweigh higher capital and operating costs associated with separate processing, packaging, and disposal of high- and low-activity waste products.) With the two product streams combined there is no need to separate solids from the scrubber blowdown, prior to drying.

- Evaporation pretreatments (PEWE, LET\&D, HLLWE) of tank farm liquids eliminated. To simplify the baseline model none of the existing evaporative pretreatment processes at Idaho Nuclear Technology and Engineering Center (INTEC) for tank farm feeds were included in the model. Such pretreatments are already well characterized on the basis of longstanding experience.

- Mercury condensation and amalgamation eliminated. To simplify the process and eliminate one waste stream (amalgamated $\mathrm{Hg}$ ) it was decided to route $\mathrm{Hg}$-laden offgas from the salt drier into the main offgas stream and thus capture the mercury in the GAC beds. This may increase the volume of waste GAC that must be disposed. Testing would be required to assess this impact.

- Replacement of final offgas cooler (condenser) with dry quench. In the original process configuration the $1000^{\circ} \mathrm{C}$ exhaust from the thermal oxidizer was assumed to be cooled in a heat exchanger and any condensation was recycled as makeup to the caustic scrub. However, the need for high-temperature materials and a specially-designed heat exchanger to handle the high temperature for this configuration suggest that a dry quench may be a better choice. This will increase the volume of offgas as a result of the evaporative cooling but the increased robustness of the system was deemed to justify the change. 
- Submerged Bed Scrubber eliminated. As discussed in Taylor \& Nichols (2002), the target models for the spray quench and the submerged bed scrubber are conceptually the same, the only difference being particle collection efficiencies owing to different operating characteristics. In the current baseline model, however, only vapor/liquid phase and chemical equilibrium is represented for these unit operations, and they are therefore equivalent. Thus, for the ASPEN Plus model their combined effect is the same as either alone, so the two were lumped into a single FLASH2 computational block.

For a more complete description of the unit operations represented in Figures 1 and 2 the reader is referred to the discussion in Taylor \& Nichols (2002). 


\section{PROCESS REPRESENTATION IN ASPEN PLUS}

ASPEN Plus was selected as the commercial process simulator of choice because of its apparent wide array of modeling capabilities (Nichols et al., 2001b). The baseline model constructed in ASPEN Plus has underlying assumptions which are described in detail in Wood (2002) and Barnes et al (2002). A brief review of pertinent details and assumptions used in constructing the model is presented below:

- The reactions that take place in the reformer are limited by the specie set, and a few have presumed extents. Thus, the portion of the model that represents the steam reformer is semimechanistic.

- Steam reformer operates at $600^{\circ} \mathrm{C}$ and 12 psia.

- Steam reformer offgas from the sintered metal product filter is quenched to $94^{\circ} \mathrm{C}$.

- Caustic scrub makeup maintains the scrub solution at a $\mathrm{pH}$ of 8.0.

- Blowdown of scrubbing liquors is required to limit buildup of dissolved and undissolved solids. As noted previously, the design philosophy for the wet offgas cleaning train was to route recycled liquid from each unit operation to the operation having the next higher level of contamination. In this manner, makeup is minimized as is the production of waste liquid that must be treated and disposed.

- A temperature of $1000^{\circ} \mathrm{C}$ will be required in the thermal oxidizer to reduce residual $\mathrm{H}_{2}, \mathrm{CO}$ and hydrocarbons below the MACT limits. (Lower temperatures are undesirable because complete oxidation may not be achieved while higher temperatures may cause undesirable thermal $\mathrm{NO}_{\mathrm{x}}$ formation.)

- Thermal oxidizer air rate adjusted to achieve $2 \mathrm{~mol}^{\circ} \mathrm{O}_{2}$ in effluent gas.

- Offgas from the thermal oxidizer is quenched to $105^{\circ} \mathrm{C}$.

- To simplify the model minor species were grouped together based on valence. Mass balance results provided by the model were transferred to a spreadsheet and the grouped species were separated back into individual components. The list of minor species treated in this way is provided in Barnes et al (2002).

- The following additives are mixed with SBW to provide the stream reformer feed:

- One mole of sucrose $\left(\mathrm{C}_{12} \mathrm{H}_{22} \mathrm{O}_{11}\right)$ for every 5 moles of $\mathrm{HNO}_{3}$ in the waste.

- Si and Al in amounts to stoichiometrically convert all Na in SBW liquid to aluminum orthosilicate $\left(\mathrm{Na}_{2} \mathrm{O} \cdot \mathrm{Al}_{2} \mathrm{O}_{3} \cdot 2 \mathrm{SiO}_{2}\right)$.

- Bed material sufficient to comprise $4 \mathrm{wt} \%$ of the final product ( $4 \%$ of final product assumed to be generated from ellutriated bed material).

- NOx catalyst at $21.6 \%$ of the bed addition rate (weight basis).

- $384 \mathrm{~kg} / \mathrm{hr}$ of steam for fluidization.

- Carbon at a rate sufficient to maintain $600^{\circ} \mathrm{C}$ temperature in the reformer (based on heat of combustion), based on assumption of $4 \mathrm{wt} \%$ carbon carryover to the primary reformer product.

- Oxygen corresponding to an assumed reducing environment in the reformer (defined as a reformer outlet $\mathrm{H}_{2}$ concentration of $1 \mathrm{~mol} \%$ ). 
- $0.5 \%$ of the reformer feed slurry carries over into the offgas treatment system.

- Composition of the reformer offgas is adjusted via specified chemical reactions with prescribed extents to achieve the following mol\% values:

$-\quad[\mathrm{CO}]=2 \%$

- $\quad\left[\mathrm{HCl}=0.73 \%\right.$ of $[\mathrm{Cl}]_{\text {total }}$

$-\quad[\mathrm{HF}]=19.5 \%$ of $[\mathrm{F}]_{\text {total }}$

- Ten $\mathrm{wt} \%$ of the reformer product is carried into the quench tower.

- Offgas scrubbing system parameters:

- Quench is adiabatic

- Quench liquid mass flow rate is 2.6 times gas flow rate

- Quench blowdown rate is $0.05 \mathrm{x}$ total offgas flow rate from steam reformer

- Scrubber is adiabatic

- Scrubber liquid mass flow rate is 7.5 times gas flow rate

- Scrubber blowdown rate is about $376 \mathrm{~kg} / \mathrm{hr}$ ( $4 \%$ of flow out scrub tank)

- $\mathrm{pH}$ of scrub makeup is equivalent to that of $0.1 \mathrm{M} \mathrm{NaOH}$ solution

- Condenser is adiabatic

- HEME is adiabatic

- HEME wash flowrate is $0.03 \mathrm{x}$ total offgas flow rate from steam reformer

- Air inflow to offgas due to vacuum flow control is $0.1 \mathrm{x}$ offgas mass flow from final HEPA filter.

The process configuration in Figure 2 was represented in ASPEN Plus with the PFD shown in Figure 3. As is customary in the use of a generic process simulation program like ASPEN Plus, multiple computational "blocks" may be required to simulate each unit operation in the process. The block/unit operation correspondence is mapped in Table 1. Target modeling approaches for the process unit operations were previously identified (Taylor, et al, 2002). 


\section{MODEL ASSESSMENT}

The steam reforming process simulation model is expected to provide the following kinds of information:

- $\quad$ Product stream compositions--Based on the input stream compositions and flowrates, the corresponding product stream characteristics are calculated based on the unit operation models and physical properties data and methods available to the simulation. The output stream characteristics can thus be compared with requirements, to the extent that the unit operation models accurately represent the underlying chemical and physical properties.

- $\quad$ Required feed and energy inputs--The model provides estimates of the compositions and flow rates of product streams, based on the compositions and feeds of the input streams. By adjusting the input streams the product streams can be tailored toward meeting requirements. In this way the simulation engineer can derive information about required feed inputs. The model also provides directly the required heat, work, and cooling inputs to the unit operations, according to the modeling assumptions (e.g., pump efficiencies, heat exchanger effectiveness, etc.).

- Operational feasibility--In addition to compositions and flowrates of product streams, similar information is provided by the model for intermediate process streams. The compositional information can be used to assess potential operational problems (e.g., corrosion, plugging). Also, assumed unit operation operating characteristics can be compared with vendor specifications of performance that can be achieved and sustained. Feasibility of providing the required feed and energy flows to/from the process can be assessed relative to program constraints (economic, infrastructure, material handling, etc.).

\section{Current Focus}

For the current phase of the SBW project, primary interest is in estimating product stream flow rates and compositions for various process configurations. Also of interest are the required feed inputs. Process energy inputs and operational feasibility are of secondary concern. The current steady-state simulation reflects these priorities, and higher-fidelity physical properties methods which require more computational effort are only used in key unit operations where streams are either combined or separated (i.e., where phase separation and/or chemical reaction of process stream components occur) and which strongly influence the characteristics of the final process streams. An offgas scrubber is considered such a key operation because it mixes the offgas stream with scrubbing solution and separates and speciates various components. A heater or cooler, on the other hand, merely changes the temperature of the stream, and a high-fidelity physical property method is not required and can be forgone in order to increase the speed of computation since energy flows are not a concern at this point.

\section{Determinants of Simulation Accuracy}

The simulation is confined within the structure of the ASPEN Plus system. This means that mathematical models have been pre-defined for most unit operations, and they generally assume thermodynamic equilibrium is achieved. Thus, finite rate processes (e.g., heat and mass transport) and physical processes (e.g., filtration and cyclonic separation) are not mechanistically represented. Consequently, the ASPEN Plus simulation represents predicted process performance based only on attainment of thermodynamic limits in partitioning and speciating the components of the input streams for each unit operation. 
There are two standards by which the fidelity of model predictions might be judged given this simulation environment: (1) They could be compared with measured parameters from tests on a real process, or (2) They could be compared with "true" thermodynamic limits obtained from theoretical calculations based on exact thermodynamic relationships and reliable thermodynamic data. "Reliable thermodynamic data" are precise measurements of thermodynamic variables obtained from carefully controlled and equilibrated experiments. Standard (1) is the one by which the utility of the model will ultimately be determined since it addresses the overall fidelity of the model. However, as noted above, ASPEN does not attempt to account for inefficiencies due to finite rate processes limited by factors other than thermodynamic considerations. Poor comparisons using standard (1) could result from its disregard for these inefficiencies. However, they could also result from poor representations of the thermodynamics of the system. Our focus at this stage is on assessing the latter source of error in ASPEN's predictions.

Given this focus, there are four principal elements of the model that determine its thermodynamic fidelity - the species set, reaction set, physical properties methods, and calculational sequence.

\section{Species Set}

Chemical partitioning of the elemental components entering a unit operation will proceed in such a way that the total Gibbs free energy of the effluent stream(s) is minimized (assuming each unit operation is at a fixed pressure and temperature). That is, in the real process the elemental building blocks spontaneously arrange themselves (over time) into whatever array of molecular, ionic, gaseous, liquid, and solid forms minimizes the free energy. The representation of this natural process in ASPEN Plus relies on a correct identification (by the user) of the complete set of chemical species that will be present after the natural equilibration process. ASPEN then calculates the quantities of each species that will (a) conserve the total molar quantities of each element present in the input streams, and (b) minimize the total free energy of the output streams. The result of the ASPEN calculation depends on the user-specified set of chemical species. Thus, different species sets result in different predicted compositions and flow rates of the output streams from the unit operations, and thus directly impacts the product stream compositions, which is the current focus in using the model (per above comments).

\section{Reaction Set}

As suggested in the foregoing paragraph, nature "arranges" the element species into different chemical and phasic forms so as to minimize free energy. In ASPEN Plus this "arranging" process is performed computationally in one of two ways: (a) According to an explicit set of reaction equations which are, again, specified by the user, or (b) By directly partitioning all elemental species into a set of user-specified products so as to minimize free energy. Method (a) must be used whenever electrolytes are present. When electrolytes are not present method (b) may be used, provided each specie which may be present in multiple phases is explicitly represented in the species list with a different entry for each phase.

When method (a) is used, the free energy minimization is performed using equilibrium constants to describe each reaction. The final equilibrium composition will contain errors if the reaction set is incomplete, or if the equilibrium constants are inaccurate. By the same token, method (b) may produce inaccurate predictions if the species list does not include all possible products that can be formed from the elemental constituents of the process streams.

\section{Physical Properties Method(s)}

Physical properties methods are mathematical models used to relate thermodynamic variables. Examples include equations of state (which provide quantitative relationships between pressure, specific volume, and temperature), activity coefficient models (which provide correction factors to 
account for non-idealities in mixtures), and transport property methods (which provide estimates of transport properties such as viscosity, thermal conductivity, etc.). The latter methods are not integral to ASPEN's thermodynamic calculations and are not considered further. Equations of state are currently used exclusively for the gas phase only and are deemed accurate since pressures in the system are generally around $1 \mathrm{~atm}$ (or lower). Thus, the focus of this discussion is on activity coefficient models.

In an ideal solution the activity coefficients of all species are 1.0, indicating zero departure from ideality. It is not uncommon in solutions of moderate ionic strength to measure activity coefficients which differ from 1.0 by one or more orders of magnitude (both higher and lower). Since the activity coefficients act as correction factors to species concentrations, this suggests that improper accounting for solution non-ideality can result in order-of-magnitude errors in predicted concentrations and phase partitioning of chemical species.

\section{Calculational Sequencing}

The architecture of the ASPEN Plus simulation is set up to do either gas phase equilibrium chemistry or aqueous phase electrolyte chemistry, but not both in a given computational block. If conditions in a block are conducive to transfer of reactive species between liquid and gas phases, then it is likely that the equilibrium composition of each phase will shift as a result of intra-phase chemistry. If the block is set up to do aqueous phase electrolyte chemistry then the gas will not be reequilibrated until it reaches a block which performs gas phase equilibrium calculations (e.g., the 'RGIBBS' does gas phase chemical equilibration through free energy minimization). This may be acceptable, provided a proper phase and chemical equilibration is performed before the stream is again partitioned into two or more separate streams. If such is not the case, the stream components may not be correctly partitioned between the exit streams and thus the final product stream compositions and flow rates will be inaccurate.

\section{Baseline Model}

\section{Species and Chemistry}

The list of species included in the baseline model is presented in Table 2, and the electrolyte reaction set is shown in Table 3. Table 4 provides information about species and physical/chemical processes expected in steam reforming process streams, based on the information in Nichols \& Taylor (2002, App. A), Barnes (2001), Patterson (1999), and Christian (2001). Column 1 of Table 4 lists the chemical species that could be present in one or more process streams. The entries in column 3 indicate the chemical transformations that are expected for each species, as follows:

- 'E-aq' indicates partial dissociation of an ionic substance in an aqueous solution (governed in the ASPEN Plus simulation by a finite equilibrium constant)

- 'E-gas' indicates chemical equilibrium of a molecular specie in a gas mixture (governed in the ASPEN Plus simulation by an overall minimization of Gibbs free energy in the gas phase)

- 'E-het' indicates chemical equilibrium between gas and pure solid in a unit operation where both phases are present

Column 5 entries indicate the types of phase transformations expected, as follows:

- $\quad$ 'SL' indicates a dissolution of a pure solid (or other non-aqueous pure phase) into component fragments (governed in ASPEN Plus by a solubility product) 
- 'VL' indicates equilibration between gaseous and aqueous forms of a specie (governed by equality of the specie fugacities in the two phases).

Finally, column 7 gives the reason that the behavior of the corresponding specie is considered important.

\section{Physical Property Methods}

The two physical property methods used are the IDEAL and the Electrolyte Non-Random TwoLiquid (ENRTL) model (Chen et al., 1982). When ENTRL is used it predicts activity coefficients for the liquid phase, and vapor phase fugacities are modeled using the Redlich-Kwong equation of state (EOS) (Aspen Technology, 2001). Some of the gaseous species are represented by Henry's law. When the IDEAL property method is selected the ideal gas law is used for the gas phase and the liquid phase solutions are assumed to be ideal (both Raoult's and Henry's laws are valid).

Table 5 shows the ASPEN Plus computational blocks and the corresponding thermodynamic property methods used in the baseline simulation. Only about $1 / 3$ of the components use the ENRTL model. On the surface this suggests that non-ideality is poorly accounted. However, as suggested by the discussion under "Calculational Sequencing," accurate phase and chemical equilibrium calculations are only critical (for the purpose of the present steady state simulation) in blocks where process streams are split into two or more outlet streams and where phase and chemical equilibrium dictates the manner in which stream components are partitioned. Examination of Figure 3 indicates that the key species-partitioning unit operations for which the simulation is expected to provide mechanistic predictions [as discussed in Taylor \& Nichols (2002)] are the QUENCH, SCRUBBER, and HEME. According to Table 5, the ENRTL method is used in all these blocks (as well as some others). Thus, the fidelity of the model to a large degree will be determined by the extent that ENRTL provides accurate accounting of non-ideality.

\section{Calculational Sequencing}

According to the brief description above, calculational sequencing should only be consequential in blocks representing unit operations where inlet streams are chemically or phasically partitioned among two or more outlet streams. In the baseline configuration of Figure 3 this occurs in the QUENCH, SCRUBBER, and HEME blocks. Ideally, to improve the fidelity of the downstream partitioning, each of these three FLASH2 blocks should be used in combination with a corresponding RGIBBS block in order to approximate simultaneous chemical and phase equilibria.

\section{Analysis of Fidelity Gaps in Baseline Model}

\section{Species and Chemistry}

The fidelity of the baseline model with respect to its species and chemistry lists was assessed by comparing entries from Table 2 and Table 3 with those in Table 4 . A check $(\sqrt{ })$ in column 2 of Table 4 indicates the corresponding specie is included in the model. Similarly, a check in columns 4 or 6 indicates the corresponding chemical or phase transformation is represented in the model. Perusal of the table shows that the following species (and their corresponding chemical and phase transformations) are missing in the model:

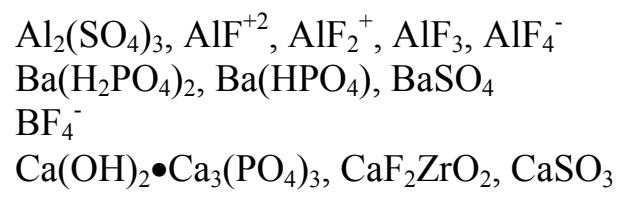




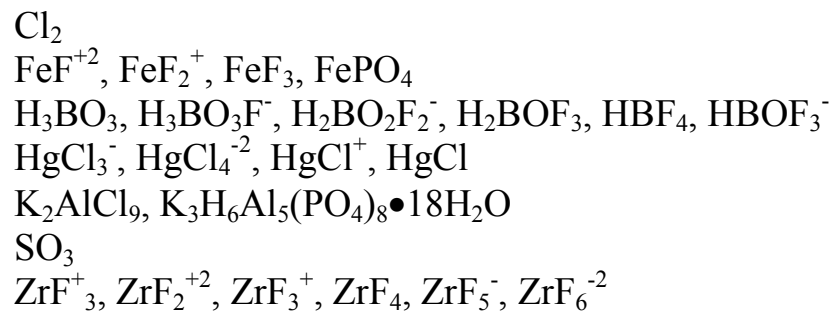

The table also shows that the following key species are present in the model but that complete representation of desired chemical and phase transformations is deficient:

$\begin{array}{ll}\mathrm{Al}\left(\mathrm{NO}_{3}\right)_{3} & \text { missing E-het } \\ \mathrm{Al}_{2} \mathrm{O}_{3} & \text { missing SL } \\ \mathrm{AlPO}_{4} & \text { missing SL } \\ \mathrm{CaO} & \text { missing SL } \\ \mathrm{Fe}_{2} \mathrm{O}_{3} & \text { missing SL } \\ \mathrm{Hg} & \text { missing E-aq, VL, SL } \\ \mathrm{Na}_{2} \mathrm{O} & \text { missing SL } \\ \mathrm{SiO}_{2} & \text { missing SL }\end{array}$

Gas phase chemical equilibration is not present in all pertinent computational blocks, and this may affect the partitioning of species which are reactive in the gas phase and are also involved with significant phase partitioning, such as $\mathrm{NO}_{2}$ and $\mathrm{HgCl}_{2}$. This condition of incomplete accounting for chemical equilibria in the gas phase is indicated by an asterick in the fourth column of Table 4.

It is noted that the baseline model species list excludes a number of minor species known to be present in the SBW feed in the interest of reducing model complexity and computer run time requirements. In order to account for the aggregate contribution of these species to the mass balance they were lumped together on the basis of valence into "pseudo" components whose chemical and physical behaviors mimic those of major species (e.g., $\mathrm{NaNO}_{3}$ for +1 cations, $\mathrm{Ca}\left(\mathrm{NO}_{3}\right)_{2}$ for +2 cations, $\mathrm{Al}\left(\mathrm{NO}_{3}\right)_{3}$ for +3 cations, and $\mathrm{HCl}$ for -1 anions). Then the ASPEN Plus output streams were "post processed" and the pseudo species separated back into individual components. This approach is reasonable provided none of the minor components so-represented are key species whose fate must be accurately predicted (for regulatory purposes, for example).

\section{Physical Property Methods}

As previously noted, the baseline model uses the ENRTL physical property method in key computational blocks and thus nominally addresses the issue of non-ideality in the aqueous phase chemistry. In order to assess the impact of the choice of physical property method on the fidelity of the process simulation, and thus establish a basis for examining alternative electrolyte models, a simple sensitivity analysis was performed. The blocks in the model which use ENRTL were changed to use the IDEAL method instead, and the ASPEN Plus model was rerun.

\footnotetext{
${ }^{\mathrm{a}}$ It is unclear whether or not heterogeneous denitration of solid $\mathrm{Al}\left(\mathrm{NO}_{3}\right)_{3}$ to form $\mathrm{Al}_{2} \mathrm{O}_{3}$ is properly accounted for in ASPEN Plus; for purposes of the present assessment it is conservatively assumed that it is not until the contrary is established.

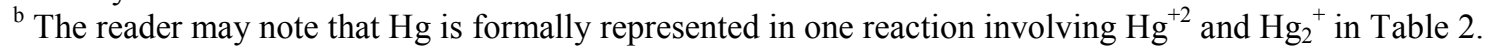
However, neither of these species is linked with any of the chloride complexes of $\mathrm{Hg}$, and thus the entire chemistry of $\mathrm{Hg} / \mathrm{Cl}$ is omitted from the model. In addition, elemental $\mathrm{Hg}$ exists primarily as a separate pure liquid phase (with very little dissolved in the aqueous phase), and it is not clear if and how Aspen Plus accounts for the partitioning of elemental $\mathrm{Hg}$ between vapor, pure liquid, and liquid aqueous phases. For these reasons it is asserted that mechanistic modeling of chemical and phase transformations of $\mathrm{Hg}$ are not represented in the current model.
} 
Table 6 provides a comparison of the stream properties and compositions for three product streams (labelled "PRODUCT", "HG-GAC", and "STACKGAS" in Figure 3) as predicted from the ENRTL and the IDEAL simulations. The table indicates that the predicted "PRODUCT" stream composition is impacted the most by the choice of property method (the average deviation is $\pm 18 \%$, and seven components have deviations greater than $\pm 50 \%$ ), and the "HG-GAC" stream is impacted the least (only three species above $\pm 5 \%$, and all below $\pm 10 \%$ ). The predicted levels of hydrofluoric acid in the final solid waste and in that sent to the stack ("PRODUCT" and "STACKGAS" streams, respectively) are appreciably different for the two property methods. Interestingly, the predicted thermodynamic properties of the streams are affected relatively little by the choice of property method, most deviations being less than $\pm 10 \%$.

Comparison for all species in the model are provided in Table 7. Almost half of the species in the simulation component list are not predicted to be present in the three selected output streams; i.e., they either experience complete chemical transformations or leave the system via the other secondary product streams. Their respective cells in Table 7 are blank because the percent deviation calculation would involve division by zero. Interestingly, the distribution of calculated deviations for the remaining species appears to be bimodal. Using the mole or mass flow basis and the "PRODUCT" stream, the majority (39 species) are in the primary group (0-10\% range), and a few (7) are in the second group encompassing the $>50 \%$ range. Only one specie falls between the two distribution humps, $\mathrm{Na}_{2} \mathrm{CO}_{3}$ at $\pm 17.5 \%$.

The fact that $15 \%[7 /(39+7+1)]$ of the species present in the solid waste form ("PRODUCT" stream) lie in the high impact group, suggests that use of a mechanistic activity coefficient model rather than assuming ideality is worthwhile. Moreover, it implies that use of a model which provides poor estimates of activity coefficients will likely impact significantly some simulation predictions of key interest (e.g., fate of HF). This observation, together will previously-published comparisons of

ENTRL with the Pitzer activity coefficient model (Nichols \& Taylor, 2002) illustrating deficiencies of the former, suggest that use of ENRTL should be phased out as a properties model for the simulation of SBW treatment as Pitzer parameter data become available to support full use of the Pitzer model.

\section{Calculational Sequencing}

The impact of the calculational sequencing gap discussed above has not yet been assessed. Prior to finalization of the next version of the model, it is anticipated that sensitivity calculations will be performed by inserting RGIBBS blocks after each significant stream partitioning block (principally the FLASH2 blocks in the model) and comparing the resulting product stream compositions (and flow rates) with those obtained without inserting the RGIBBS blocks. 


\section{CONCLUSIONS}

The current baseline simulation provides a good start for estimating a mass balance. It includes chemical and phase transformations for several key species, such as nitrates, carbonates, and key acids $\left(\mathrm{HNO}_{3}, \mathrm{H}_{2} \mathrm{SO}_{4}\right.$, and $\left.\mathrm{HCl}\right)$. It uses a mechanistic electrolyte model, ENRTL, where appropriate. All the key unit operations are included to provide a means to perform integrated process optimization.

The simulation can be improved to enhance its predictive fidelity. Chemical and phase transformations for key mercury, boric, aluminum, zirconium, barium, and iron species are absent and need to be added. Chemical equilibrium in the gas phase is not accounted for in the off-gas treatment train (downstream of the reformer), which may decrease the accuracy of the phase partitioning predicted in the scrubber, quench, and mist eliminator unit operations.

Appreciable benefit is derived from using an activity coefficient model for electrolyte solution thermodynamics rather than assuming ideality. The concentrations of fifteen percent of the species present in the primary output stream are changed by more than $50 \%$ when the ENRTL activity coefficient model is used in place of thermodynamic calculations assuming solution ideality.

\section{Path Forward}

Nichols and Taylor (2002) demonstrated the superiority of the Pitzer ion-interaction model over ENRTL to predict electrolyte solution thermodynamics. Given the impact of accounting for non-ideal behavior documented here, demonstrated by comparing the ENRTL and IDEAL scenarios, it is recommended that current efforts to determine Pitzer parameters for key species be continued and that the Pitzer model replace ENRTL in SBW simulations. In addition, chemical and phase transformations for key mercury, boric, aluminum, zirconium, barium, and iron species should be added to the model. Finally, it is recommended that RGIBBS blocks be combined with the current scrubber, quench and mist eliminator FLASH2 blocks in the off-gas treatment train in order to simulate simultaneous phase and chemical equilibria. 


\section{REFERENCES}

Aspen Technology (2001), Aspen Physical Property System: Physical Property Methods and Models 11.1, Appendix C: Pitzer Activity Coefficient Model, September, Aspen Technology, Inc.: Cambridge, MA.

Barnes, C.M. (2001), Feed Composition for the Sodium-Bearing Waste Treatment Process, INEEL/EXT-2000-01378, July.

Barnes, C.M., R.A. Wood, and B.H. O'Brien (2002), Process Design of Sodium-Bearing Waste Treatment Alternatives, EDF-2373, to be published in August.

Chen, Chau-Chyun, H.I. Britt, J.F. Boston, and L.B. Evans (1982), "Local Composition Model for Excess Gibbs Energy of Electrolyte Systems, Part I: Single Solvent, Single Completely Dissociated Electrolyte Systems", AIChE Journal, Vol. 28, No. 4, July, 1982, pp. 588-596.

Christian, J.D. (2001), Composition and Simulation of Tank WM-180 Sodium-Bearing Waste at the Idaho Nuclear Technology and Engineering Center, INEEL/EXT-2001-00600, July.

Hammer, R.R. (1979), A Determination of the Stability Constants of a Number of Metal Fluoride Complexes and Their Rates of Formation, ENICO-1004, August.

Nichols, Todd T., Dean D. Taylor, Lance Lauerhass, Charles M. Barnes (2001a), Simulation of HighLevel Waste Treatment Process Trains at Idaho National Engineering \& Environmental Laboratory - Scope, INEEL/EXT-01-00345 (Rev. 0), March.

Nichols, Todd T., Charles M. Barnes, Lance Lauerhass, and Dean D. Taylor (2001b), Selection of Steady-State Process Simulation Software to Optimize Treatment of Radioactive and Hazardous Waste, INEEL/EXT-01-00485, May.

Nichols, Todd T. and Dean D. Taylor (2002), Physical Properties Models For Simulation Of Processes To Treat INEEL Tank Farm Waste: Thermodynamic Equilibrium, INEEL/EXT-0200877, Rev. 0, July.

Patterson, M. (1999), Light Duty Utility Arm Deployment in Tank WM-188, INEEL/EXT-99-01302, December.

Swenson, M. (2002), telecon with D.D. Taylor on 7/30/02.

Taylor, Dean D., Charles M. Barnes, and Todd T. Nichols (2002), Process Options Description for Steam Reforming Flowsheet Model of INEEL Tank Farm Waste, INEEL/EXT-02-00545, Rev. 0 , May.

Wood, R.A.(2002), Interoffice Memorandum to C.M. Barnes, Subject: Revision To Steam Reforming Process Write-Up, DBEs, PFD, Material Balances, \& Equipment Sizing Calculations, July 16.

Studsvik, Inc. (2000), Idaho High-Level Waste and Facilities Disposition Draft Environmental Impact Statement (DOE/EIS-0287D) Studsvik, Inc. Comments, Control \# DC-57, April 12.

Gentilucci, J.A., J.E. Miller, R.L. Treat, and W.W. Schulz (2001), Technical Review of the Applicability of the Studsvik, Inc. THOR ${ }^{S M}$ Process to INEEL SBW, TFA-0101, March.

Marshall, D.W. and J. Pao (2000), Scoping Tests for Steam Reformation of Simulated Low-Activity Waste (DRAFT), September.

WGI (2002), Studsvik THOR ${ }^{\text {sm }}$ Steam Reformer Technical Feasibility Study (DRAFT A), WGI/RL/0102. 


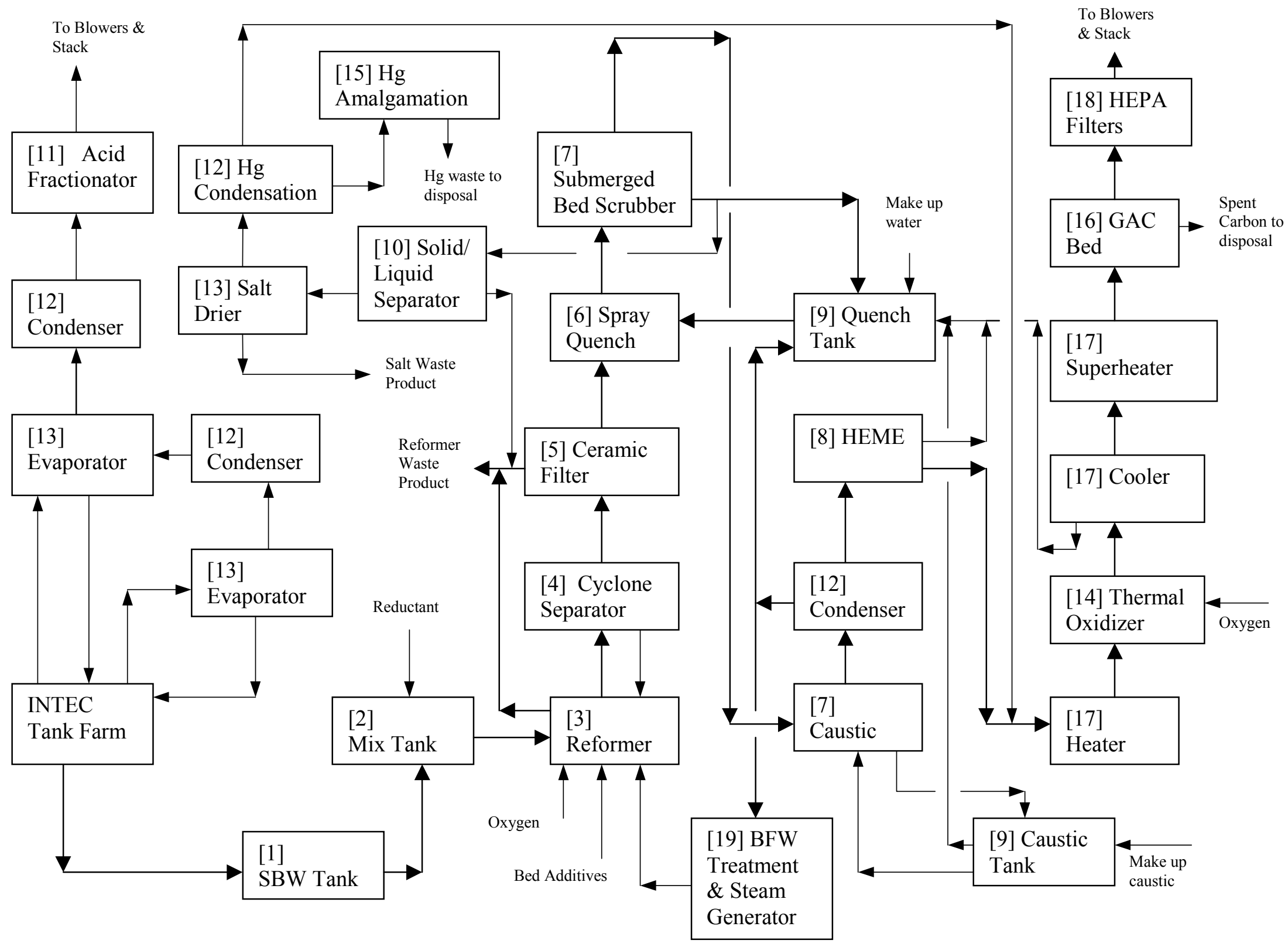

Figure 1. Original Steam Reforming Process Configuration [from Taylor et al. (2002)]. 


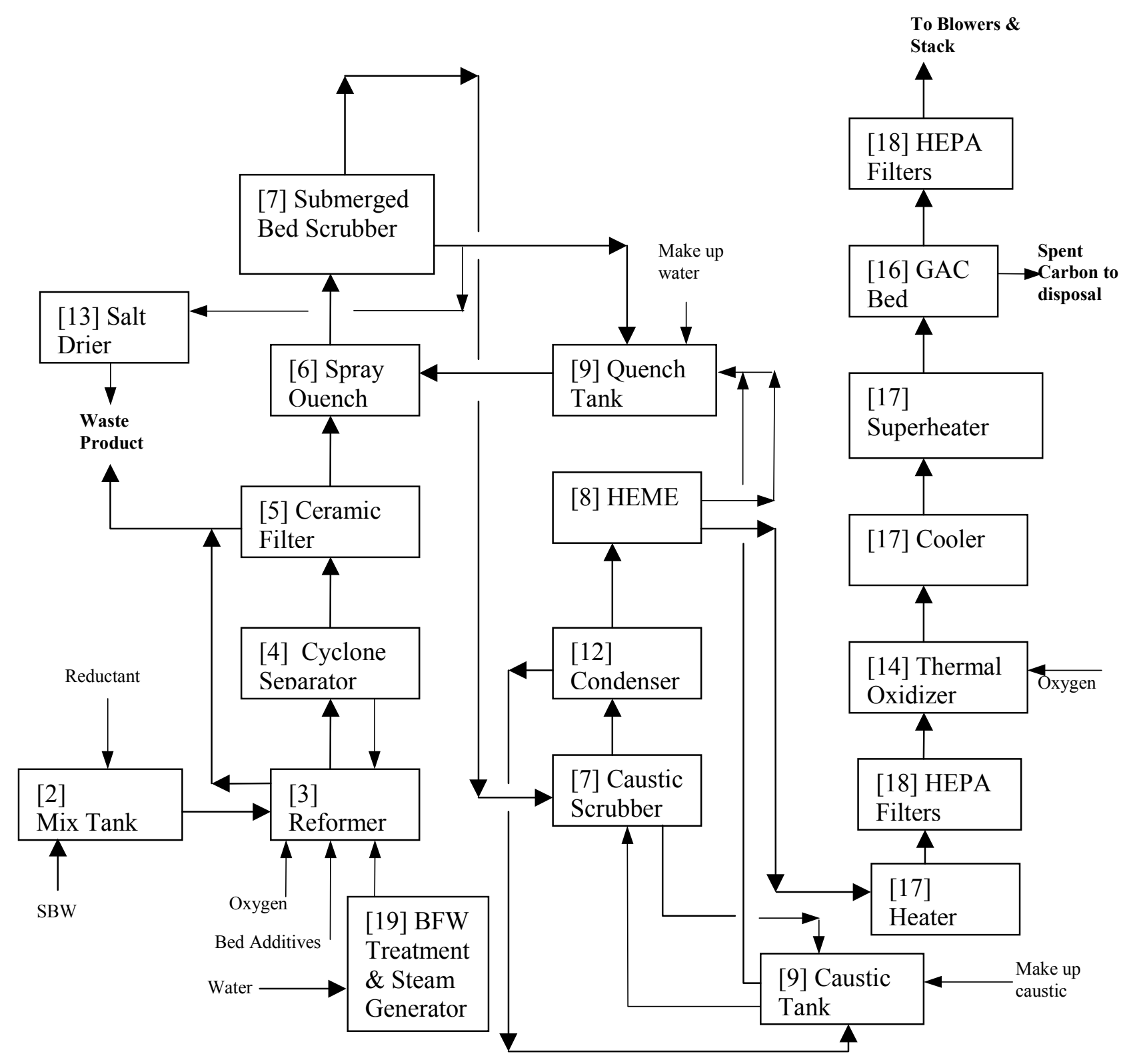

Figure 2. Revised Steam Reforming Process Configuration. 
SBW Steam Reforming Simulation

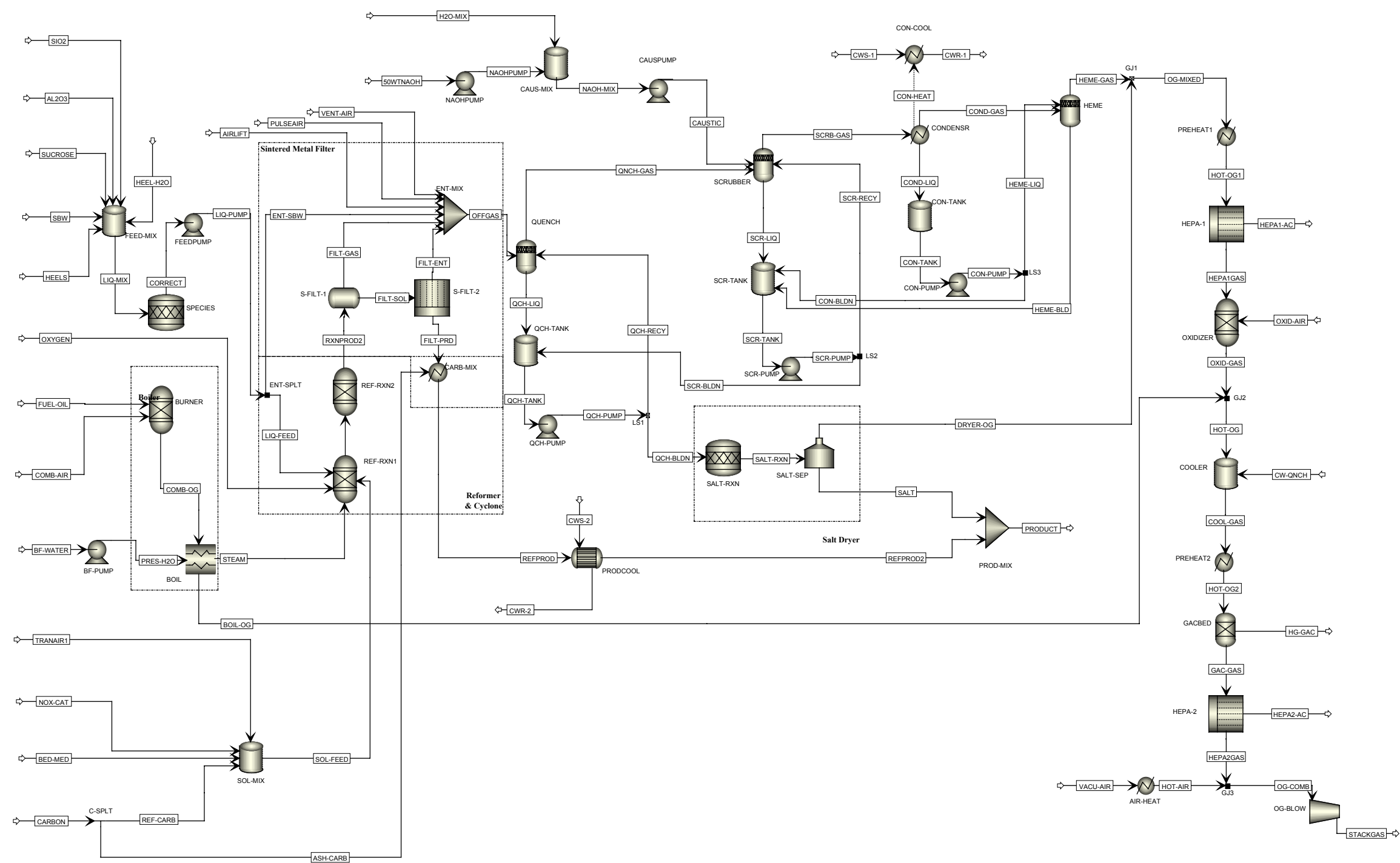

Figure 3. ASPEN Plus Process Flow Diagram. 
Table 1. Process Configuration/ASPEN PFD Matrix.

\begin{tabular}{|c|c|c|}
\hline \multicolumn{2}{|r|}{ Process Configuration $^{a}$} & \multirow{2}{*}{ ASPEN Plus PFD } \\
\hline Type ID & Name & \\
\hline [2] & Mix Tank & $\begin{array}{l}\text { FEEDMIX } \\
\text { SPECIES }\end{array}$ \\
\hline [3] & Reformer & $\begin{array}{l}\text { REF-RXN2 } \\
\text { REF-RXN2 }\end{array}$ \\
\hline [4] & Cyclone Separator & S-FILT-1 \\
\hline [5] & Ceramic Filter & S-FILT-2 \\
\hline [6] & Spray Quench & QUENCH + \\
\hline [7] & Submerged Bed Scrubber & QUENCH ${ }_{*}^{+}$ \\
\hline [7] & Caustic Scrubber & SCRUBBER \\
\hline [8] & HEME & HEME \\
\hline [9] & Quench Tank & QCH-TANK \\
\hline [9] & Caustic Tank & SCR-TANK \\
\hline [12] & Condenser (Offgas) & CONDENSR \\
\hline$[13]$ & Salt Dryer & $\begin{array}{l}\text { SALT-RXN } \\
\text { SALT-SEP }\end{array}$ \\
\hline [14] & Thermal Oxidizer & OXIDIZER \\
\hline [16] & GAC Bed & GACBED \\
\hline [17] & Heater & PREHEAT1 \\
\hline [17] & Cooler & COOLER \\
\hline [17] & Superheater & PREHEAT2 \\
\hline [18] & HEPA Filters (Top) & HEPA-2 \\
\hline [18] & HEPA Filters (Bottom) & HEPA-1 \\
\hline [19] & BFW Treatment \& Steam Generator & $\begin{array}{l}\text { BURNER } \\
\text { BOIL }\end{array}$ \\
\hline
\end{tabular}

${ }^{\text {a }}$ From Figure 2. ${ }^{\mathrm{b}}$ From Figure 3. $\ddagger$ The baseline model does not yet incorporate a separate aerosol stream with a particle size distribution; therefore, the Quench and Submerged Bed Scrubber are regarded as equivalent unit operations and their overall effect is represented with the single QUENCH block. Once the model is refined to reflect the effects of particle size on separation efficiencies these two operations will be split into two blocks. 
Table 2. List Of Species In Baseline ASPEN Plus Model.

\begin{tabular}{|c|c|c|c|}
\hline ASPEN & ASPEN & ASPEN Component name & Formula \\
\hline Component ID & Type & & \\
\hline $\mathrm{AL}(\mathrm{NO} 3) 3$ & CONV & ALUMINUM NITRATE NONAHYDRATE & ALN3O9*9W \\
\hline $\mathrm{AL}+++$ & CONV & $\mathrm{AL}+++$ & $A L+3$ \\
\hline AL2O3 & SOLID & ALUMINIUM-OXIDE-ALPHA-CORUNDUM & AL2O3 \\
\hline ALNO3(S) & SOLID & ALUMINUM-NITRATE-NONAHYDRATE & ALN3O9*9W \\
\hline ALPO4 & SOLID & ALUMINIUM-PHOSPHATE-ORTHO & ALPO4-O \\
\hline $\mathrm{C} 2 \mathrm{H} 6$ & CONV & ETHANE & $\mathrm{C} 2 \mathrm{H} 6$ \\
\hline $\mathrm{C} 3 \mathrm{H} 8$ & CONV & PROPANE & $\mathrm{C} 3 \mathrm{H} 8$ \\
\hline $\mathrm{CA}(\mathrm{NO} 3) 2$ & CONV & CALCIUM-NITRATE & $\mathrm{CA}(\mathrm{NO} 3) 2$ \\
\hline CA++ & CONV & $\mathrm{CA}++$ & $\mathrm{CA}+2$ \\
\hline CACL2(S) & SOLID & CALCIUM-CHLORIDE & CACL2 \\
\hline CACO3 & SOLID & CALCIUM-CARBONATE & CACO3 \\
\hline CAF2 & SOLID & CALCIUM-FLUORIDE & CAF2 \\
\hline CANO3(S) & SOLID & CALCIUM-NITRATE & $\mathrm{CA}(\mathrm{NO} 3) 2$ \\
\hline CAO & SOLID & CALCIUM-OXIDE & CAO \\
\hline $\mathrm{CAOH}+$ & CONV & $\mathrm{CAOH}+$ & $\mathrm{CAOH}+$ \\
\hline CARBON & SOLID & CARBON(GRAPHITE) & C \\
\hline CASO4(S) & SOLID & CALCIUM-SULFATE & CASO4 \\
\hline $\mathrm{CH} 4$ & CONV & METHANE & $\mathrm{CH} 4$ \\
\hline CL- & CONV & CL- & CL- \\
\hline $\mathrm{CO}$ & CONV & CARBON-MONOXIDE & $\mathrm{CO}$ \\
\hline $\mathrm{CO} 2$ & CONV & CARBON-DIOXIDE & $\mathrm{CO} 2$ \\
\hline CO3-- & CONV & CO3-- & CO3-2 \\
\hline F- & CONV & F- & F- \\
\hline FE2O3 & SOLID & FERRIC-OXIDE & FE2O3 \\
\hline $\mathrm{H} 2$ & CONV & HYDROGEN & $\mathrm{H} 2$ \\
\hline $\mathrm{H} 2 \mathrm{O}$ & CONV & WATER & $\mathrm{H} 2 \mathrm{O}$ \\
\hline $\mathrm{H} 2 \mathrm{~S}$ & CONV & HYDROGEN-SULFIDE & $\mathrm{H} 2 \mathrm{~S}$ \\
\hline $\mathrm{H} 2 \mathrm{SO} 4$ & CONV & SULFURIC-ACID & $\mathrm{H} 2 \mathrm{SO} 4$ \\
\hline $\mathrm{H} 3 \mathrm{O}+$ & CONV & $\mathrm{H} 3 \mathrm{O}+$ & $\mathrm{H} 3 \mathrm{O}+$ \\
\hline $\mathrm{HCL}$ & CONV & HYDROGEN-CHLORIDE & $\mathrm{HCL}$ \\
\hline HCO3- & CONV & $\mathrm{HCO}-$ & $\mathrm{HCO}-$ \\
\hline HF & CONV & HYDROGEN-FLUORIDE & HF \\
\hline HG & CONV & MERCURY & HG \\
\hline $\mathrm{HG}(\mathrm{OH}) 2$ & CONV & MERCURY-DIHYDROXIDE & $\mathrm{HG}(\mathrm{OH}) 2$ \\
\hline $\mathrm{HG}++$ & CONV & $\mathrm{HG}++$ & $\mathrm{HG}+2$ \\
\hline HG2++ & CONV & HG2++ & $\mathrm{HG} 2+2$ \\
\hline HGCL2 & CONV & MERCURY-DICHLORIDE & HGCL2 \\
\hline $\mathrm{HGOH}+$ & CONV & $\mathrm{HGOH}+$ & $\mathrm{HGOH}+$ \\
\hline HNO3 & CONV & NITRIC-ACID & HNO3 \\
\hline HS- & CONV & HS- & HS- \\
\hline HSO3- & CONV & HSO3- & HSO3- \\
\hline HSO4- & CONV & HSO4- & HSO4- \\
\hline $\mathrm{K}+$ & CONV & $\mathrm{K}+$ & $\mathrm{K}+$ \\
\hline $\mathrm{K} 2 \mathrm{CO} 3$ & SOLID & POTASSIUM-CARBONATE & $\mathrm{K} 2 \mathrm{CO} 3$ \\
\hline K2O & SOLID & POTASSIUM-OXIDE & K2O \\
\hline K2SO4 & SOLID & POTASSIUM-SULFATE & K2SO4 \\
\hline K3PO4 & SOLID & POTASSIUM-PHOSPHATE & K3PO4 \\
\hline $\mathrm{KCL}$ & SOLID & POTASSIUM-CHLORIDE & $\mathrm{KCL}$ \\
\hline
\end{tabular}




\begin{tabular}{|c|c|c|c|}
\hline $\begin{array}{c}\text { ASPEN } \\
\text { Component ID }\end{array}$ & $\begin{array}{c}\text { ASPEN } \\
\text { Type }\end{array}$ & ASPEN Component name & Formula \\
\hline $\mathrm{KHCO} 3$ & SOLID & POTASSIUM-BICARBONATE & KHCO3 \\
\hline KHSO4 & SOLID & KHSO4 & KHSO4 \\
\hline KNO3 & CONV & POTASSIUM-NITRATE & KNO3 \\
\hline KNO3(S) & SOLID & POTASSIUM-NITRATE & KNO3 \\
\hline $\mathrm{KOH}(\mathrm{S})$ & SOLID & POTASSIUM-HYDROXIDE & $\mathrm{KOH}$ \\
\hline MINUS1 & CONV & HYDROGEN-CHLORIDE & $\mathrm{HCL}$ \\
\hline N2 & CONV & NITROGEN & N2 \\
\hline $\mathrm{NA}+$ & CONV & $\mathrm{NA}+$ & $\mathrm{NA}+$ \\
\hline NA2CO3 & SOLID & SODIUM-CARBONATE & NA2CO3 \\
\hline NA2O & SOLID & SODIUM-OXIDE & NA2O \\
\hline NA2S & SOLID & SODIUM-SULFIDE & NA2S \\
\hline NA2SO3 & SOLID & SODIUM-SULFITE & NA2SO3 \\
\hline NA2SO4 & SOLID & SODIUM-SULFATE & NA2SO4 \\
\hline NA3PO4 & CONV & TRISODIUM-PHOSPHATE & NA3PO4 \\
\hline NA3PO4(S & SOLID & TRISODIUM-PHOSPHATE & NA3PO4 \\
\hline NAALO2 & SOLID & NAALO2 & NAALO2 \\
\hline NACL & SOLID & SODIUM-CHLORIDE & NACL \\
\hline NAF & SOLID & NAF & NAF \\
\hline $\mathrm{NAHCO} 3$ & SOLID & SODIUM-HYDROGEN-CARBONATE & NAHCO3 \\
\hline NAHS & CONV & NAHS & NAHS \\
\hline NAHS(S) & SOLID & NAHS & NAHS \\
\hline NAHSO4 & SOLID & SODIUM-BISULFATE & NAHSO4 \\
\hline NANO3 & CONV & SODIUM-NITRATE & NANO3 \\
\hline NANO3(S) & SOLID & SODIUM-NITRATE & NANO3 \\
\hline $\mathrm{NAOH}$ & CONV & $\mathrm{NAOH}$ & $\mathrm{NAOH}$ \\
\hline $\mathrm{NAOH}(\mathrm{S})$ & SOLID & SODIUM-HYDROXIDE & $\mathrm{NAOH}$ \\
\hline $\mathrm{N}-\mathrm{HEX}-01$ & CONV & N-HEXADECANE & $\mathrm{C} 16 \mathrm{H} 34$ \\
\hline NO & CONV & NITRIC-OXIDE & NO \\
\hline NO2 & CONV & NITROGEN-DIOXIDE & NO2 \\
\hline NO3- & CONV & NO3- & NO3- \\
\hline $\mathrm{O} 2$ & CONV & OXYGEN & $\mathrm{O} 2$ \\
\hline $\mathrm{OH}-$ & CONV & $\mathrm{OH}-$ & $\mathrm{OH}-$ \\
\hline PLUS1 & SOLID & SODIUM-NITRATE & NANO3 \\
\hline PLUS2 & SOLID & CALCIUM-NITRATE & $\mathrm{CA}(\mathrm{NO} 3) 2$ \\
\hline PLUS3 & SOLID & ALUMINUM-NITRATE-NONAHYDRATE & ALN3O9*9W \\
\hline PLUS4 & SOLID & ZIRCONIUM-DIOXIDE & ZRO2 \\
\hline PLUS5 & SOLID & DIVANADIUM-PENTAOXIDE & V2O5 \\
\hline PLUS6 & SOLID & MOLYBDENUM-TRIOXIDE & MOO3 \\
\hline S-- & CONV & S-- & S-2 \\
\hline $\mathrm{SIO} 2$ & SOLID & SILICON-DIOXIDE & $\mathrm{SIO} 2$ \\
\hline $\mathrm{SO} 2$ & CONV & SULFUR-DIOXIDE & $\mathrm{O} 2 \mathrm{~S}$ \\
\hline SO3-- & CONV & SO3-- & SO3-2 \\
\hline SO4-- & CONV & SO4-- & SO4-2 \\
\hline SUCROSE & SOLID & SUCROSE & $\mathrm{C} 12 \mathrm{H} 22 \mathrm{O} 11$ \\
\hline
\end{tabular}


Table 3. List Of Reactions In Baseline ASPEN Plus Electrolyte Chemistry.

\begin{tabular}{|c|c|c|}
\hline Reaction & Type & Stoichiometry \\
\hline 1 & Equilibrium & $2 \mathrm{H} 2 \mathrm{O}<-->\mathrm{H} 3 \mathrm{O}++\mathrm{OH}-$ \\
\hline 2 & Equilibrium & $\mathrm{H} 2 \mathrm{~S}+\mathrm{H} 2 \mathrm{O}<-->\mathrm{H} 3 \mathrm{O}++\mathrm{HS}-$ \\
\hline 3 & Equilibrium & $\mathrm{HS}-+\mathrm{H} 2 \mathrm{O}<-->\mathrm{H} 3 \mathrm{O}+$ + S-- \\
\hline 4 & Equilibrium & $\mathrm{CO} 2+2 \mathrm{H} 2 \mathrm{O}<-->\mathrm{H} 3 \mathrm{O}+$ + HCO3- \\
\hline 5 & Equilibrium & HCO3- + $\mathrm{H} 2 \mathrm{O}<-->\mathrm{H} 3 \mathrm{O}+$ + CO3-- \\
\hline 6 & Equilibrium & $\mathrm{H} 2 \mathrm{SO} 4+\mathrm{H} 2 \mathrm{O}<-->\mathrm{H} 3 \mathrm{O}++\mathrm{HSO}_{-}$ \\
\hline 7 & Equilibrium & HSO4- + H2O <--> H3O+ + SO4-- \\
\hline 8 & Equilibrium & $\mathrm{HCL}+\mathrm{H} 2 \mathrm{O}<-->\mathrm{H} 3 \mathrm{O}++\mathrm{CL}-$ \\
\hline 9 & Equilibrium & $\mathrm{HF}+\mathrm{H} 2 \mathrm{O}<-->\mathrm{H}_{3} \mathrm{O}+$ + F- \\
\hline 10 & Equilibrium & HNO3 + H2O <--> H3O+ + NO3- \\
\hline 11 & Equilibrium & $\mathrm{SO} 2+2 \mathrm{H} 2 \mathrm{O}<-->\mathrm{H} 3 \mathrm{O}++\mathrm{HSO}_{-}$ \\
\hline 12 & Equilibrium & HSO3- + H2O <--> H3O+ + SO3-- \\
\hline 13 & Equilibrium & $\mathrm{HG}+++\mathrm{HG}<-->\mathrm{HG} 2++$ \\
\hline 14 & Equilibrium & $\mathrm{HG}+++2 \mathrm{H} 2 \mathrm{O}<-->\mathrm{H} 3 \mathrm{O}++\mathrm{HGOH}+$ \\
\hline 15 & Equilibrium & $\mathrm{HGOH}++2 \mathrm{H} 2 \mathrm{O}<-->\mathrm{H} 3 \mathrm{O}++\mathrm{HG}(\mathrm{OH}) 2$ \\
\hline 16 & Equilibrium & $\mathrm{CAOH}+<-->\mathrm{CA}+++\mathrm{OH}-$ \\
\hline NACL & Salt & $\mathrm{NACL}<->\mathrm{NA}++\mathrm{CL}-$ \\
\hline $\mathrm{NA2SO} 4$ & Salt & NA2SO4 <--> $2 \mathrm{NA}+$ + SO4-- \\
\hline $\mathrm{K} 2 \mathrm{CO} 3$ & Salt & $\mathrm{K} 2 \mathrm{CO} 3<-->2 \mathrm{~K}++\mathrm{CO} 3--$ \\
\hline $\mathrm{KHCO} 3$ & Salt & $\mathrm{KHCO} 3<-->\mathrm{K}+$ + HCO3- \\
\hline $\mathrm{NAOH}(\mathrm{S})$ & Salt & $\mathrm{NAOH}(\mathrm{S})<-->\mathrm{NA}++\mathrm{OH}-$ \\
\hline $\mathrm{KOH}(\mathrm{S})$ & Salt & $\mathrm{KOH}(\mathrm{S})<-->\mathrm{K}++\mathrm{OH}-$ \\
\hline CACL2(S) & Salt & CACL2(S) <--> CA++ + 2 CL- \\
\hline CANO3(S) & Salt & CANO3(S) <--> CA++ + 2 NO3- \\
\hline CASO4(S) & Salt & CASO4(S) <--> CA++ + SO4-- \\
\hline CAF2 & Salt & CAF2 <--> CA++ + 2 F- \\
\hline $\mathrm{KCL}$ & Salt & $\mathrm{KCL}<-->\mathrm{K}++\mathrm{CL}-$ \\
\hline KHSO4 & Salt & KHSO4 <--> K+ + HSO4- \\
\hline $\mathrm{KNO} 3(\mathrm{~S})$ & Salt & $\mathrm{KNO3}(\mathrm{S})<-->\mathrm{K}+$ + NO3- \\
\hline $\mathrm{K} 2 \mathrm{SO} 4$ & Salt & $\mathrm{K} 2 \mathrm{SO} 4<-->2 \mathrm{~K}++$ SO4-- \\
\hline NA2CO3 & Salt & NA2CO3 <--> $2 \mathrm{NA}++$ CO3-- \\
\hline NAF & Salt & NAF <--> NA+ + F- \\
\hline $\mathrm{NAHCO} 3$ & Salt & $\mathrm{NAHCO} 3<-->\mathrm{NA}++\mathrm{HCO} 3-$ \\
\hline NANO3(S) & Salt & NANO3(S) <--> NA+ + NO3- \\
\hline NA2S & Salt & NA2S <--> 2 NA+ + S-- \\
\hline NA2SO3 & Salt & NA2SO3 <--> $2 \mathrm{NA}+$ + SO3-- \\
\hline $\mathrm{CACO} 3$ & Salt & CACO3 <--> CA++ + CO3-- \\
\hline NAHSO4 & Salt & NAHSO4 <--> NA+ + HSO4- \\
\hline $\mathrm{NAHS}(\mathrm{S})$ & Salt & $\mathrm{NAHS}(\mathrm{S})<-->\mathrm{NA}++\mathrm{HS}-$ \\
\hline ALNO3(S) & Salt & ALNO3(S) <--> AL+++ + 3. NO3- + 9. H2O \\
\hline $\mathrm{NAOH}$ & Dissociation & $\mathrm{NAOH}-->\mathrm{NA}++\mathrm{OH}-$ \\
\hline $\mathrm{CA}(\mathrm{NO} 3) 2$ & Dissociation & $\mathrm{CA}(\mathrm{NO} 3) 2-->\mathrm{CA}+++2 \mathrm{NO}-$ \\
\hline KNO3 & Dissociation & KNO3 --> K+ + NO3- \\
\hline NANO3 & Dissociation & NANO3 --> NA+ + NO3- \\
\hline
\end{tabular}


Table 4. Species, Reactions, and Phase Transformations Needed for Simulation.

\begin{tabular}{|c|c|c|c|c|c|}
\hline Specie & & $\begin{array}{l}\text { Ch } \\
\text { Trf. }^{\text {a }}\end{array}$ & $\begin{array}{l}\mathrm{Ph} \\
\text { Trf. }^{\mathrm{b}}\end{array}$ & & Rationale \\
\hline $\mathrm{Al}(\mathrm{NO} 3) 3$ & $\sqrt{ }$ & E-het & SL & $\sqrt{ }$ & $\begin{array}{l}\mathrm{Al}+3 \text { and NO3- are major species in the waste feed } \\
\text { and the formation of } \mathrm{Al}(\mathrm{NO} 3) 3 \text { and its inclusion in } \\
\text { solid products is of interest because of its effect on } \\
\text { agglomeration behavior during solids transport and } \\
\text { handling. } \\
\text { (see also comment under 'NaNO3', which may be } \\
\text { applicable due to limited solubility of Al(NO3)3) }\end{array}$ \\
\hline $\mathrm{A} 12(\mathrm{SO} 4) 3$ & & E-aq & SL & & $\begin{array}{l}\text { Due to the abundance of } \mathrm{Al} \text { in the feed, } \mathrm{A} 12(\mathrm{SO} 4) 3 \\
\text { may be formed from the sulfate in the reformer. The } \\
\text { fate of sulfate is of interest (see 'H2SO4'). } \\
\text { (also see comments under ' } \mathrm{Ca}(\mathrm{OH}) 2 \cdot \mathrm{Ca} 3(\mathrm{PO} 4) 3 \text { ') }\end{array}$ \\
\hline $\mathrm{A} 12 \mathrm{O} 3$ & $\sqrt{ }$ & & SL & & $\begin{array}{l}\mathrm{Al} \text { is a major component of TDS in waste and } \mathrm{Al} 2 \mathrm{O} 3 \\
\text { will be major contributor to solid product and } \mathrm{PM} \\
\text { loading in offgas. Its fate will determine equipment } \\
\text { sizing. } \\
\mathrm{A} 12 \mathrm{O} 3 \text { will likely be a major contributor to UDS in } \\
\text { scrub solutions, and may determine solid/liquid } \\
\text { separation requirements and pumping system } \\
\text { requirements for scrub recycle. }\end{array}$ \\
\hline $\mathrm{AlF}+2$ & & E-aq & & & $\begin{array}{l}\text { Aluminum complexes with fluoride impact chemistry } \\
\text { of HF (Hammer, 1979). See 'HF'. }\end{array}$ \\
\hline AlF2+ & & E-aq & & & $($ see 'AlF+2') \\
\hline AlF3 & & E-aq & & & $($ see 'AlF+2'). \\
\hline A1F4- & & E-aq & & & $($ see 'AlF+2'). \\
\hline $\mathrm{AlPO} 4$ & $\sqrt{ }$ & E-aq & SL & & (same comment as for ' $\mathrm{Ca}(\mathrm{OH}) 2 \bullet \mathrm{Ca} 3(\mathrm{PO} 4) 3 ')$ \\
\hline $\mathrm{Ba}(\mathrm{H} 2 \mathrm{PO} 4) 2$ & & E-aq & SL & & $\begin{array}{l}\text { Ba was a significant cation in solids samples from } \\
\text { tank farm tank WM-188 (Patterson, 1999) and PO4-3 } \\
\text { is a major constituent of solid samples from the tank } \\
\text { farm (Barnes, 2001),(Patterson, 1999). Ba+2/PO4-3 } \\
\text { salts may account for these facts and should be } \\
\text { considered if blended solution stabilities and solids } \\
\text { formation are of interest. }\end{array}$ \\
\hline $\mathrm{Ba}(\mathrm{HPO} 4)$ & & E-aq & SL & & (see 'Ba(H2PO4)2') \\
\hline $\mathrm{BaSO} 4$ & & E-aq & SL & & $\begin{array}{l}\text { Ba was a significant cation in solids samples from } \\
\text { tank farm tank WM-188 (Patterson, 1999). BaSO4 is } \\
\text { a sparingly soluble salt that may account for this and } \\
\text { should be considered if blended solution stabilities } \\
\text { and solids formation are of interest. }\end{array}$ \\
\hline BF4- & & E-aq & & & (see 'H3BO3F-') \\
\hline $\begin{array}{l}\mathrm{Ca}(\mathrm{OH}) 2 \\
\text {-Ca3(PO4)3 }\end{array}$ & & E-aq & SL & & $\begin{array}{l}\text { PO4-3 is a major constituent of solid samples from } \\
\text { the tank farm (Barnes, 2001), (Patterson, 1999). The } \\
\text { species at left has been identified as possible } \\
\text { precipitate from tank farm solutions (Christian, 2001) } \\
\text { and should be considered if blended solution } \\
\text { stabilities and solids formation are of interest. }\end{array}$ \\
\hline $\mathrm{CaCl} 2$ & $\sqrt{ }$ & & SL & $\sqrt{ }$ & $\begin{array}{l}\text { Chemistry of } \mathrm{CaCl} 2 \text { impacts fate of } \mathrm{Cl}-\text {, which } \\
\text { impacts fate of } \mathrm{HCl} \text { and } \mathrm{Cl} 2 \text {. }\end{array}$ \\
\hline $\mathrm{CaCO} 3$ & $\sqrt{ }$ & & SL & $\sqrt{ }$ & $\begin{array}{l}\mathrm{Ca} \text { is a significant cation in the waste feed. } \mathrm{CaCO} 3 \\
\text { will likely be part of the reformer product. It may }\end{array}$ \\
\hline
\end{tabular}




\begin{tabular}{|c|c|c|c|c|c|c|}
\hline Specie & & $\begin{array}{l}\mathrm{Ch} \\
\text { Trf. }^{\text {a }}\end{array}$ & & $\begin{array}{c}\mathrm{Ph} \\
\text { Trf. }^{\mathrm{b}}\end{array}$ & & Rationale \\
\hline & & & & & & $\begin{array}{l}\text { impact scrub solution } \mathrm{pH} \text {, UDS concentrations, and } \\
\text { handling characteristics of solid waste product. }\end{array}$ \\
\hline $\mathrm{CaF} 2$ & $\sqrt{ }$ & & & SL & $\sqrt{ }$ & $\begin{array}{l}\text { Chemistry of CaF2 impacts fate of F-, which impacts } \\
\text { fate of HF (see 'HF'). } \\
\text { CaF2 may contribute significantly to UDS in scrub } \\
\text { solutions (see 'Al2O3'). }\end{array}$ \\
\hline $\mathrm{CaF} 2 \mathrm{ZrO} 2$ & & & & SL & & $\begin{array}{l}\mathrm{Zr} \text { is a major cation in tank farm solids samples } \\
\text { (Barnes, 2001), (Patterson, 1999), (Christian, 2001) } \\
\text { and calcium fluorozirconate was mentioned as a } \\
\text { commonly-encountered solid in tank farm samples } \\
\text { (Swenson, 2002) }\end{array}$ \\
\hline $\mathrm{CaO}$ & $\sqrt{ }$ & & & SL & & $\begin{array}{l}\text { Hygroscopicity of } \mathrm{CaO} \text { in reformer product may } \\
\text { impact handling characteristics. }\end{array}$ \\
\hline $\mathrm{CaSO} 3$ & & & & SL & & (see comments under ' Al2(SO4)3') \\
\hline $\mathrm{CaSO} 4$ & $\sqrt{ }$ & & & SL & $\sqrt{ }$ & ('CaCO3' comments apply) \\
\hline $\mathrm{Cl} 2$ & & E-gas & $*$ & VL & & $\mathrm{Cl} 2$ concentration in offgas regulated by MACT. \\
\hline $\mathrm{CO}$ & $\sqrt{ }$ & $\begin{array}{l}\text { E-gas } \\
\text { E-het }\end{array}$ & * & & & $\begin{array}{l}\mathrm{CO} \text { is an explosion hazard and a MACT-regulated } \\
\text { pollutant--concentrations must be known to design } \\
\text { required control measures. }\end{array}$ \\
\hline $\mathrm{CO} 2$ & $\sqrt{ }$ & $\begin{array}{c}\text { E-gas } \\
\text { E-aq }\end{array}$ & * & VL & $\sqrt{ }$ & $\begin{array}{l}\mathrm{CO} 2 \text { is part of chemistry of } \mathrm{CO} \text { and of metal } \\
\text { carbonates . } \\
\text { It will also be a major diluent in offgas if water vapor } \\
\text { is removed and will contribute to oxidation chemistry } \\
\text { of HCs and CO in thermal oxidizer. }\end{array}$ \\
\hline $\mathrm{Fe} 2 \mathrm{O} 3$ & $\sqrt{ }$ & & & SL & & $\begin{array}{l}\text { Fe2O3 may be a major contributor to UDS in scrub } \\
\text { solutions (see 'A12O3'). }\end{array}$ \\
\hline $\mathrm{FeF}+2$ & & E-aq & & & & $\begin{array}{l}\text { Iron complexes with fluoride impact chemistry of HF } \\
\text { (Hammer, 1979). See 'HF'. }\end{array}$ \\
\hline $\mathrm{FeF} 2+$ & & E-aq & & & & $\left(\right.$ see $^{\prime} \mathrm{FeF}+2$ ') \\
\hline FeF3 & & E-aq & & & & $($ see ' $\mathrm{FeF}+2 ')$ \\
\hline FePO4 & & E-aq & & SL & & (same comment as for ' $\left.\mathrm{Ca}(\mathrm{OH}) 2 \bullet \mathrm{Ca} 3(\mathrm{PO} 4) 3^{\prime}\right)$ \\
\hline $\mathrm{H} 2$ & $\sqrt{ }$ & E-gas & * & VL & $\sqrt{ }$ & $\begin{array}{l}\mathrm{H} 2 \text { is an explosion hazard--concentrations must be } \\
\text { known to determine required control measures. }\end{array}$ \\
\hline $\mathrm{H} 2 \mathrm{BO} 2 \mathrm{~F} 2-$ & & E-aq & & & & (see 'H3BO3F-') \\
\hline H2BOF3 & & E-aq & & & & (see 'H3BO3F-') \\
\hline $\mathrm{H} 2 \mathrm{O}$ & $\sqrt{ }$ & $\begin{array}{c}\text { E-gas } \\
\text { E-aq }\end{array}$ & $\begin{array}{l}* \\
\sqrt{ }\end{array}$ & VL & $\sqrt{ }$ & $\begin{array}{l}\mathrm{H} 2 \mathrm{O} \text { is part of gas phase chemistry of many other } \\
\text { species of interest. It will be the largest single } \\
\text { component of offgas and scrub solutions. Its fate will } \\
\text { determine equipment sizing. }\end{array}$ \\
\hline $\mathrm{H} 2 \mathrm{~S}$ & $\sqrt{ }$ & E-gas & $*$ & VL & $\sqrt{ }$ & $\begin{array}{l}\mathrm{H} 2 \mathrm{~S} \text { is toxic and its concentration will be of interest } \\
\text { to regulators. }\end{array}$ \\
\hline $\mathrm{H} 2 \mathrm{SO} 4$ & $\sqrt{ }$ & $\begin{array}{c}\text { E-gas } \\
\text { E-aq }\end{array}$ & $\begin{array}{l}* \\
\sqrt{ }\end{array}$ & VL & $\sqrt{ }$ & $\begin{array}{l}\mathrm{H} 2 \mathrm{SO} 4 \text { is part of chemistry of } \mathrm{H} 2 \mathrm{~S} \text {. Also, fate of } \\
\text { sulfate may be of interest in case the reformer } \\
\text { product is ever vitrified. }\end{array}$ \\
\hline $\mathrm{H} 3 \mathrm{BO} 3$ & & E-aq & & & & $\begin{array}{l}\text { Boric acid participates in borate chemistry (see } \\
\text { 'H3BO3F-'). }\end{array}$ \\
\hline H3BO3F- & & E-aq & & & & $\begin{array}{l}\text { Borates form soluble complexes with F- and thus are } \\
\text { an integral part of the chemistry (Hammer, 1979) of } \\
\text { HF. }\end{array}$ \\
\hline HBF4 & & E-aq & & & & (see 'H3BO3F-') \\
\hline HBOF3- & & E-aq & & & & (see 'H3BO3F-') \\
\hline
\end{tabular}




\begin{tabular}{|c|c|c|c|c|c|c|}
\hline Specie & & $\begin{array}{l}\text { Ch } \\
\text { Trf. }^{\text {a }}\end{array}$ & & $\begin{array}{l}\mathrm{Ph} \\
\text { Trf. }\end{array}$ & & Rationale \\
\hline $\mathrm{HCl}$ & $\sqrt{ }$ & $\begin{array}{l}\text { E-aq } \\
\text { E-gas }\end{array}$ & $\begin{array}{l}\sqrt{ } \\
*\end{array}$ & VL & $\sqrt{ }$ & $\mathrm{HCl}$ concentration in offgas regulated by MACT. \\
\hline $\mathrm{HF}$ & $\sqrt{ }$ & E-aq & $\sqrt{ }$ & VL & $\sqrt{ }$ & $\begin{array}{l}\text { HF is highly toxic and will be regulated in offgas. } \\
\text { HF is corrosive and its concentration is needed for } \\
\text { material specifications. }\end{array}$ \\
\hline $\mathrm{Hg}$ & $\sqrt{ }$ & E-aq & & $\begin{array}{l}\text { VL } \\
\text { SL }\end{array}$ & & $\begin{array}{l}\mathrm{Hg} \text { in stack gas is regulated to a very low } \\
\text { concentration under MACT and } \mathrm{Hg} \text { in solid wastes is } \\
\text { indirectly regulated through LDR restrictions on } \\
\text { TCLP concentrations. Fate of } \mathrm{Hg} \text { is needed to design } \\
\text { acceptable control measures for stack gas } \\
\text { concentrations and to develop suitable measures to } \\
\text { tailor solid waste forms to satisfy TCLP limits. }\end{array}$ \\
\hline $\mathrm{HgCl}$ & & E-aq & & SL & & $\mathrm{HgCl}$ (calomel) is part of chemistry of $\mathrm{Hg}$. \\
\hline $\mathrm{HgCl}+$ & & E-aq & & & & (see 'HgCl3-') \\
\hline $\mathrm{HgCl} 2$ & $\sqrt{ }$ & E-aq & & $\begin{array}{l}\text { VL } \\
\text { SL }\end{array}$ & $\begin{array}{l}\sqrt{ } \\
\sqrt{ }\end{array}$ & $\begin{array}{l}\mathrm{HgCl} 2 \text { is much more soluble than } \mathrm{Hg} \text { and thus can } \\
\text { strongly influence mercury partitioning between } \\
\text { liquid and gas phases provided the required redox } \\
\text { conditions prevail. } \\
\text { (see also ' } \mathrm{Hg}^{\prime} \text { ) }\end{array}$ \\
\hline $\mathrm{HgCl} 3-$ & & E-aq & & & & $\begin{array}{l}\text { Soluble } \mathrm{Hg}+2 / \mathrm{Cl} \text { - complexes are part of chemistry of } \\
\mathrm{Hg} \text {. }\end{array}$ \\
\hline $\mathrm{HgCl} 4-2$ & & E-aq & & & & (see 'HgCl3-') \\
\hline HNO3 & $\sqrt{ }$ & E-aq & $\sqrt{ }$ & VL & $\sqrt{ }$ & $\begin{array}{l}\text { NO3- is the largest component of the feed and will } \\
\text { result in large quantities of NOx in offgas. Fate of } \\
\text { HNO3 and NO2 will impact pH of scrub solutions. } \\
\text { NOx emissions will be regulated by state and HNO3 } \\
\text { chemistry is part of NO2 chemistry. }\end{array}$ \\
\hline $\mathrm{K} 2 \mathrm{AlCl9}$ & & E-aq & & SL & & (same comment as for ' $\left.\mathrm{Ca}(\mathrm{OH}) 2 \bullet \mathrm{Ca} 3(\mathrm{PO} 4) 3{ }^{\prime}\right)$ \\
\hline $\begin{array}{l}\text { K3H6A15(PO4)8 } \\
\bullet 18 \mathrm{H} 2 \mathrm{O}\end{array}$ & & E-aq & & SL & & (same comment as for ' $\mathrm{Ca}(\mathrm{OH}) 2 \bullet \mathrm{Ca} 3(\mathrm{PO} 4) 3{ }^{\prime}$ ) \\
\hline KNO3 & $\sqrt{ }$ & & & SL & $\sqrt{ }$ & $\begin{array}{l}\text { KNO3 was identified in solids from tank farm } \\
\text { solutions (Christian, 2001) and should be considered } \\
\text { if blended solution stabilities and solids formation } \\
\text { are of interest. }\end{array}$ \\
\hline $\mathrm{N} 2$ & $\sqrt{ }$ & E-gas & $*$ & VL & $\sqrt{ }$ & $\mathrm{N} 2$ is part of $\mathrm{NO} 2$ and $\mathrm{HNO} 3$ chemistry \\
\hline $\mathrm{Na} 2 \mathrm{CO} 3$ & $\sqrt{ }$ & & & SL & $\sqrt{ }$ & ('CaCO3' comments apply) \\
\hline $\mathrm{Na} 2 \mathrm{O}$ & $\sqrt{ }$ & & & SL & & $\begin{array}{l}\mathrm{Na}+\text { is the } 2 \text { nd most abundant cation (excluding } \mathrm{H}+\text { ) } \\
\text { in the feed and will likely be converted to } \mathrm{Na} 2 \mathrm{O} \text { in } \\
\text { the reformer. It will impact } \mathrm{pH} \text { of scrubber solutions } \\
\text { and will likely form submicron aerosols that will } \\
\text { penetrate to the HEPA filters and dictate their } \\
\text { changeout frequency. } \\
\text { Hygroscopicity of Na2O in product may impact } \\
\text { handling characteristics. }\end{array}$ \\
\hline $\mathrm{Na} 2 \mathrm{SO} 4$ & $\sqrt{ }$ & & & SL & $\sqrt{ }$ & ('CaCO3' comments apply) \\
\hline NaNO3 & $\sqrt{ }$ & & & SL & $\sqrt{ }$ & $\begin{array}{l}\mathrm{Na}+\text { and NO3- were the most abundant cation and } \\
\text { anion, respectively identified in tank farm tank WM- } \\
180 \text { and it has been inferred that the liquid was } \\
\text { supersaturated in NaNO3 (Christian, 2001). } \\
\text { NaNO3(s) should thus be considered if blended } \\
\text { solution stabilities and solids formation are of }\end{array}$ \\
\hline
\end{tabular}




\begin{tabular}{|c|c|c|c|c|c|c|}
\hline Specie & & $\begin{array}{l}\mathrm{Ch} \\
\text { Trf. }^{\text {a }}\end{array}$ & & $\begin{array}{l}\mathrm{Ph} \\
\text { Trf. }\end{array}$ & & Rationale \\
\hline & & & & & & interest. \\
\hline NO & $\sqrt{ }$ & E-gas & * & & & $\begin{array}{l}\text { NO is part of the oxidation chemistry of } \mathrm{NO} 2 \text { and } \\
\text { N2. }\end{array}$ \\
\hline NO2 & $\sqrt{ }$ & $\begin{array}{c}\text { E-gas } \\
\text { E-aq }\end{array}$ & $*$ & VL & $\sqrt{ }$ & $\begin{array}{l}\text { NO2 concentrations dictate oxidizing potential of } \\
\text { offgas and will strongly impact speciation of } \mathrm{Hg} \text {. } \\
\text { (see also 'HNO3') }\end{array}$ \\
\hline $\mathrm{O} 2$ & $\sqrt{ }$ & E-gas & * & VL & $\sqrt{ }$ & $\begin{array}{l}\mathrm{O} 2 \text { is part of gas phase chemistry of } \mathrm{H} 2, \mathrm{CO} \text {, and } \\
\text { hydrocarbons (HCs) formed in reformer and will } \\
\text { impact their concentrations. }\end{array}$ \\
\hline $\mathrm{SiO} 2$ & $\sqrt{ }$ & E-aq & & SL & & $\begin{array}{l}\text { Si has been identified as a significant component of } \\
\text { solids in tank farm tank WM-180 (Christian, 2001). } \\
\text { (see comment for ' } \mathrm{Ca}(\mathrm{OH}) 2 \bullet \mathrm{Ca} 3(\mathrm{PO} 4) 3 \text { ') }\end{array}$ \\
\hline $\mathrm{SO} 2$ & $\sqrt{ }$ & E-gas & $*$ & VL & $\sqrt{ }$ & (see comments under 'H2SO4') \\
\hline $\mathrm{SO} 3$ & & $\begin{array}{l}\text { E-gas } \\
\text { E-aq }\end{array}$ & $*$ & VL & & (see comments under 'H2SO4') \\
\hline $\mathrm{ZrF}+3$ & & E-aq & & & & $\begin{array}{l}\mathrm{Zr}+4 \text { forms several soluble complexes with F- and } \\
\text { thus is an integral part of the chemistry (Hammer, } \\
1979 \text { ) of HF. }\end{array}$ \\
\hline $\mathrm{ZrF} 2+2$ & & E-aq & & & & (see ' $\mathrm{ZrF}+3$ ') \\
\hline ZrF3+ & & E-aq & & & & $($ see ' $\mathrm{ZrF}+3 ')$ \\
\hline $\mathrm{ZrF} 4$ & & E-aq & & & & (see ' $\mathrm{ZrF}+3$ ') \\
\hline ZrF5- & & E-aq & & & & $($ see 'ZrF+3') \\
\hline ZrF6-2 & & E-aq & & & & (see ' $\mathrm{ZrF}+3$ ') \\
\hline
\end{tabular}

$\sqrt{ } \Rightarrow>$ specie or transformation is present in baseline model. ${ }^{a}$ 'E-aq'=partial aqueous dissociation, 'E-gas'=equilibrium gas phase reaction, 'E-het'=equilibrium heterogeneous reaction (gas/solid). ${ }^{\mathrm{b}}$ 'SL'=solid/liquid phase equilibrium, 'VL'=vapor/liquid phase equilibrium. * See discussion under section Calculational Sequencing. 
Table 5. Thermodynamic Property Methods Currently Used By Unit Operation Blocks In ASPEN Plus Baseline Simulation.

\begin{tabular}{|c|c|c|c|}
\hline \multirow{2}{*}{ NAME } & \multirow{2}{*}{ TYPE } & \multicolumn{2}{|c|}{ Phase } \\
\hline & & Liquid & Gas \\
\hline OG-BLOW & COMPR & IDEAL & - \\
\hline CONDENSR & FLASH2 & ENRTL & ENRTI \\
\hline HEME & FLASH2 & ENRTL & ENRTI \\
\hline QUENCH & FLASH2 & ENRTL & ENRTI \\
\hline SALT-SEP & FLASH2 & IDEAL & IDEAI \\
\hline SCRUBBER & FLASH2 & ENRTL & ENRTI \\
\hline S-FILT-1 & FLASH2 & IDEAL & IDEAI \\
\hline C-SPLT & FSPLIT & IDEAL & IDEAI \\
\hline LS1 & FSPLIT & - & ENRTI \\
\hline LS2 & FSPLIT & ENRTL & - \\
\hline LS3 & FSPLIT & ENRTL & - \\
\hline AIR-HEAT & HEATER & - & IDEAI \\
\hline CARB-MIX & HEATER & IDEAL & IDEAI \\
\hline $\mathrm{CON}-\mathrm{COOL}$ & HEATER & IDEAL & - \\
\hline PREHEAT1 & HEATER & - & IDEAI \\
\hline PREHEAT2 & HEATER & - & IDEAI \\
\hline PRODCOOL & HEATX & IDEAL & IDEAI \\
\hline BOIL & MHEATX & IDEAL & IDEAI \\
\hline CAUS-MIX & MIXER & ENRTL & - \\
\hline CON-TANK & MIXER & ENRTL & - \\
\hline COOLER & MIXER & - & ENRTI \\
\hline ENT-MIX & MIXER & IDEAL & IDEAI \\
\hline FEED-MIX & MIXER & IDEAL & - \\
\hline GJ1 & MIXER & IDEAL & IDEAI \\
\hline GJ2 & MIXER & IDEAL & IDEAI \\
\hline GJ3 & MIXER & - & IDEAI \\
\hline PROD-MIX & MIXER & IDEAL & IDEAI \\
\hline QCH - TANK & MIXER & ENRTL & - \\
\hline SCR-TANK & MIXER & ENRTL & - \\
\hline SOL-MIX & MIXER & IDEAL & IDEAI \\
\hline BF - PUMP & PUMP & IDEAL & - \\
\hline CAUSPUMP & PUMP & ENRTL & - \\
\hline CON-PUMP & PUMP & ENRTL & - \\
\hline FEEDPUMP & PUMP & - & IDEAI \\
\hline NAOHPUMP & PUMP & ENRTL & - \\
\hline QCH - PUMP & PUMP & ENRTL & - \\
\hline SCR - PUMP & PUMP & ENRTL & - \\
\hline BURNER & RGIBBS & IDEAL & IDEAI \\
\hline OXIDIZER & RGIBBS & IDEAL & IDEAI \\
\hline REF-RXN1 & RGIBBS & IDEAL & IDEAI \\
\hline REF-RXN2 & RSTOIC & IDEAL & IDEAI \\
\hline SALT-RXN & RSTOIC & IDEAL & IDEAI \\
\hline SPECIES & RSTOIC & IDEAL & - \\
\hline GACBED & SEP & IDEAL & - \\
\hline ENT-SPLT & SSPLIT & IDEAL & IDEAI \\
\hline $\mathrm{HEPA}-1$ & SSPLIT & - & IDEAI \\
\hline HEPA-2 & SSPLIT & IDEAL & IDEAI \\
\hline S-FILT-2 & SSPLIT & IDEAL & IDEAI \\
\hline
\end{tabular}


Table 6. Comparison of ENRTL and IDEAL Property Methods (Summary).

\begin{tabular}{|c|c|c|c|}
\hline \multirow[t]{2}{*}{ Specie } & \multicolumn{3}{|c|}{$\begin{array}{c}\text { Per Cent Absolute Deviation }{ }^{\mathrm{a}} \text { of ENRTL } \\
\text { from IDEAL }>5 \%\end{array}$} \\
\hline & PRODUCT & HG-GAC & STACKGAS \\
\hline $\mathrm{CO} 2$ & 9.89 & & 0.15 \\
\hline $\mathrm{H} 2 \mathrm{O}$ & 9.10 & & 3.99 \\
\hline HCL & 0.00 & & 8.72 \\
\hline $\mathrm{HF}$ & 66.23 & & 99.94 \\
\hline $\mathrm{HG}^{\mathrm{b}}$ & 0.48 & 8.62 & 8.62 \\
\hline NA2CO3 & 17.49 & & \\
\hline NAHSO4 & 97.03 & & \\
\hline NAHS & 54.30 & & \\
\hline NA2S & 99.92 & & \\
\hline CARBON $^{c}$ & 0.97 & 9.43 & \\
\hline NAHCO3 & 274.52 & & \\
\hline $\mathrm{OH}-$ & 100.00 & & \\
\hline MINUS1 ${ }^{\mathrm{b}}$ & & 8.72 & \\
\hline $\mathrm{CAOH}+$ & 99.97 & & \\
\hline \multicolumn{4}{|l|}{ Stream Statistics } \\
\hline Maximum & 274.52 & 8.72 & 99.94 \\
\hline Minimum & 0.00 & 0.00 & 0.00 \\
\hline Average & 17.65 & 5.78 & 9.02 \\
\hline Standard Deviation & 48.44 & 5.01 & 26.34 \\
\hline \multicolumn{4}{|l|}{ Stream Properties } \\
\hline Total Flow kmol/day & 0.89 & 8.62 & 2.71 \\
\hline Total Flow kg/hr & 0.98 & 8.62 & 2.21 \\
\hline Total Flow 1/hr & 1.02 & 8.65 & 2.70 \\
\hline Temperature $\mathrm{C}$ & 0.00 & 0.00 & 0.03 \\
\hline Pressure atm & 0.00 & 0.00 & 0.00 \\
\hline Enthalpy cal/mol & 0.01 & 3.44 & 0.71 \\
\hline Enthalpy cal/gm & 0.10 & 3.44 & 1.20 \\
\hline Enthalpy cal/sec & 0.87 & 11.76 & 3.45 \\
\hline Entropy cal/mol-K & 9.58 & 1.50 & 7.23 \\
\hline Entropy cal/gm-K & 9.66 & 1.50 & 7.76 \\
\hline Density mol/cc & 0.13 & 0.04 & 0.01 \\
\hline Density gm/cc & 0.04 & 0.03 & 0.47 \\
\hline Average MW & 0.09 & 0.00 & 0.48 \\
\hline Liq Vol 60F 1/hr & & 8.62 & 1.76 \\
\hline
\end{tabular}


Table 7. Comparison Between ENRTL and IDEAL Property Methods (Complete Specie Data).

\begin{tabular}{|c|c|c|c|c|c|c|c|c|c|}
\hline \multirow[b]{3}{*}{ SPECIE } & \multicolumn{9}{|c|}{ PER CENT ABSOLUTE DEVIATION OF ENRTL FROM IDEAL ${ }^{\text {a }}$} \\
\hline & \multicolumn{3}{|c|}{ MOLE OR MASS FLOW } & \multicolumn{3}{|c|}{ MOLE FRACTION } & \multicolumn{3}{|c|}{ MASS FRACTION } \\
\hline & $\begin{array}{l}\mathbf{P} \\
\mathbf{R} \\
\mathbf{O} \\
\mathbf{D} \\
\mathbf{U} \\
\mathbf{C} \\
\mathbf{T}\end{array}$ & $\begin{array}{l}\mathbf{H} \\
\mathbf{G} \\
- \\
\mathbf{G} \\
\mathbf{A} \\
\mathbf{C}\end{array}$ & $\begin{array}{l}\mathbf{S} \\
\mathbf{T} \\
\mathbf{A} \\
\mathbf{C} \\
\mathbf{K} \\
\mathbf{G} \\
\mathbf{A} \\
\mathbf{S} \\
\end{array}$ & $\begin{array}{l}\mathbf{P} \\
\mathbf{R} \\
\mathbf{O} \\
\mathbf{D} \\
\mathbf{U} \\
\mathbf{C} \\
\mathbf{T}\end{array}$ & $\begin{array}{l}\mathbf{H} \\
\mathbf{G} \\
- \\
\mathbf{G} \\
\mathbf{A} \\
\mathbf{C}\end{array}$ & $\begin{array}{l}\mathbf{S} \\
\mathbf{T} \\
\mathbf{A} \\
\mathbf{C} \\
\mathbf{K} \\
\mathbf{G} \\
\mathbf{A} \\
\mathbf{S} \\
\end{array}$ & $\begin{array}{l}\mathbf{P} \\
\mathbf{R} \\
\mathbf{O} \\
\mathbf{D} \\
\mathbf{U} \\
\mathbf{C} \\
\mathbf{T}\end{array}$ & $\begin{array}{l}\mathbf{H} \\
\mathbf{G} \\
- \\
\mathbf{G} \\
\mathbf{A} \\
\mathbf{C}\end{array}$ & $\begin{array}{l}\mathbf{S} \\
\mathbf{T} \\
\mathbf{A} \\
\mathbf{C} \\
\mathbf{K} \\
\mathbf{G} \\
\mathbf{A} \\
\mathbf{S} \\
\end{array}$ \\
\hline $\mathrm{H} 2$ & 0.00 & & 0.00 & 0.88 & & 2.64 & 0.97 & & 2.16 \\
\hline $\mathrm{CO}$ & 0.00 & & 0.00 & 0.88 & & 2.64 & 0.97 & & 2.17 \\
\hline $\mathrm{CO} 2$ & 9.89 & & 0.15 & 10.68 & & 2.79 & 10.76 & & 2.31 \\
\hline $\mathrm{O} 2$ & 0.00 & & 1.01 & 0.88 & & 1.66 & 0.97 & & 1.18 \\
\hline $\mathrm{N} 2$ & 0.00 & & 0.48 & 0.88 & & 2.17 & 0.97 & & 1.69 \\
\hline $\mathrm{NO}$ & & & 0.00 & & & 2.64 & & & 2.17 \\
\hline $\mathrm{NO} 2$ & & & 0.50 & & & 3.12 & & & 2.65 \\
\hline $\mathrm{H} 2 \mathrm{~S}$ & 0.06 & & & 0.82 & & & 0.91 & & \\
\hline $\mathrm{SO} 2$ & 0.00 & & 0.68 & 0.88 & & 1.98 & 0.97 & & 1.51 \\
\hline $\mathrm{H} 2 \mathrm{O}$ & 9.10 & & 3.99 & 8.14 & & 1.24 & 8.05 & & 1.73 \\
\hline HNO3 & & & 1.79 & & & 4.38 & & & 3.92 \\
\hline HCL & 0.00 & & 8.72 & 0.88 & & 11.13 & 0.97 & & 10.70 \\
\hline HF & 66.23 & & 99.94 & 66.53 & & 99.95 & 66.56 & & 99.95 \\
\hline $\mathrm{H} 2 \mathrm{SO} 4$ & & & 0.45 & & & 2.20 & & & 1.72 \\
\hline HG & 0.48 & 8.62 & 8.62 & 0.40 & 0.00 & 11.03 & 0.49 & 0.00 & 10.60 \\
\hline HGCL2 & 0.37 & & & 0.51 & & & 0.60 & & \\
\hline NA2CO3 & 17.49 & & & 18.21 & & & 18.29 & & \\
\hline $\mathrm{K} 2 \mathrm{CO} 3$ & 0.00 & & & 0.88 & & & 0.97 & & \\
\hline $\mathrm{CACO} 3$ & 0.00 & & & 0.88 & & & 0.97 & & \\
\hline NA2O & 0.00 & & & 0.88 & & & 0.97 & & \\
\hline $\mathrm{K} 2 \mathrm{O}$ & & & & & & & & & \\
\hline $\mathrm{CAO}$ & 0.00 & & & 0.88 & & & 0.97 & & \\
\hline NAALO2 & & & & & & & & & \\
\hline AL2O3 & 0.00 & & & 0.88 & & & 0.97 & & \\
\hline SIO2 & 0.00 & & & 0.88 & & & 0.97 & & \\
\hline FE2O3 & 0.00 & & & 0.88 & & & 0.97 & & \\
\hline NACL & 0.00 & & & 0.88 & & & 0.97 & & \\
\hline KCL & 0.00 & & & 0.88 & & & 0.97 & & \\
\hline CAF2 & & & & & & & & & \\
\hline NANO3 & 0.00 & & & 0.88 & & & 0.97 & & \\
\hline NANO3(S) & & & & & & & & & \\
\hline KNO3 & & & & & & & & & \\
\hline KNO3(S) & & & & & & & & & \\
\hline $\mathrm{CA}(\mathrm{NO} 3) 2$ & & & & & & & & & \\
\hline CANO3(S) & & & & & & & & & \\
\hline AL(NO3)3 & 0.00 & & & 0.88 & & & 0.97 & & \\
\hline ALNO3(S) & & & & & & & & & \\
\hline NAHSO4 & 97.03 & & & 97.06 & & & 97.06 & & \\
\hline NA2SO4 & 0.00 & & & 0.88 & & & 0.97 & & \\
\hline NAHS & 54.30 & & & 52.94 & & & 52.80 & & \\
\hline NAHS(S) & 0.00 & & & 0.88 & & & 0.97 & & \\
\hline NA2S & 99.92 & & & 99.92 & & & 99.92 & & \\
\hline
\end{tabular}




\begin{tabular}{|c|c|c|c|c|c|c|c|c|c|}
\hline \multirow[b]{3}{*}{ SPECIE } & \multicolumn{9}{|c|}{ PER CENT ABSOLUTE DEVIATION OF ENRTL FROM IDEAL } \\
\hline & \multicolumn{3}{|c|}{ MOLE OR MASS FLOW } & \multicolumn{3}{|c|}{ MOLE FRACTION } & \multicolumn{3}{|c|}{ MASS FRACTION } \\
\hline & $\begin{array}{l}\mathbf{P} \\
\mathbf{R} \\
\mathbf{O} \\
\mathbf{D} \\
\mathbf{U} \\
\mathbf{C} \\
\mathbf{T}\end{array}$ & $\begin{array}{c}\mathbf{H} \\
\mathbf{G} \\
- \\
\mathbf{G} \\
\mathbf{A} \\
\mathbf{C}\end{array}$ & $\begin{array}{l}\mathbf{S} \\
\mathbf{T} \\
\mathbf{A} \\
\mathbf{C} \\
\mathbf{K} \\
\mathbf{G} \\
\mathbf{A} \\
\mathbf{S}\end{array}$ & $\begin{array}{l}\mathbf{P} \\
\mathbf{R} \\
\mathbf{O} \\
\mathbf{D} \\
\mathbf{U} \\
\mathbf{C} \\
\mathbf{T}\end{array}$ & $\begin{array}{l}\mathbf{H} \\
\mathbf{G} \\
- \\
\mathbf{G} \\
\mathbf{A} \\
\mathbf{C}\end{array}$ & $\begin{array}{l}\mathbf{S} \\
\mathbf{T} \\
\mathbf{A} \\
\mathbf{C} \\
\mathbf{K} \\
\mathbf{G} \\
\mathbf{A} \\
\mathbf{S}\end{array}$ & $\begin{array}{l}\mathbf{P} \\
\mathbf{R} \\
\mathbf{O} \\
\mathbf{D} \\
\mathbf{U} \\
\mathbf{C} \\
\mathbf{T}\end{array}$ & $\begin{array}{c}\mathbf{H} \\
\mathbf{G} \\
- \\
\mathbf{G} \\
\mathbf{A} \\
\mathbf{C}\end{array}$ & $\begin{array}{l}\mathbf{S} \\
\mathbf{T} \\
\mathbf{A} \\
\mathbf{C} \\
\mathbf{K} \\
\mathbf{G} \\
\mathbf{A} \\
\mathbf{S}\end{array}$ \\
\hline $\mathrm{NAOH}$ & 0.22 & & & 1.09 & & & 1.18 & & \\
\hline SUCROSE & 0.01 & & & 0.87 & & & 0.96 & & \\
\hline CARBON & 0.00 & 0.00 & & 0.88 & 9.43 & & 0.97 & 9.43 & \\
\hline NA2SO3 & 0.00 & & & 0.88 & & & 0.97 & & \\
\hline NAHCO3 & 274.52 & & & 271.23 & & & 270.90 & & \\
\hline NAF & 0.18 & & & 0.70 & & & 0.79 & & \\
\hline K2SO4 & 0.00 & & & 0.88 & & & 0.97 & & \\
\hline KHSO4 & & & & & & & & & \\
\hline KHCO3 & & & & & & & & & \\
\hline $\mathrm{AL}+++$ & & & & & & & & & \\
\hline $\mathrm{H} 3 \mathrm{O}+$ & & & & & & & & & \\
\hline NA+ & & & & & & & & & \\
\hline $\mathrm{K}+$ & & & & & & & & & \\
\hline $\mathrm{CA}++$ & & & & & & & & & \\
\hline HG++ & & & & & & & & & \\
\hline HSO3- & & & & & & & & & \\
\hline NO3- & & & & & & & & & \\
\hline F- & & & & & & & & & \\
\hline HSO4- & & & & & & & & & \\
\hline CL- & & & & & & & & & \\
\hline $\mathrm{HCO} 3-$ & & & & & & & & & \\
\hline HS- & & & & & & & & & \\
\hline SO3-- & & & & & & & & & \\
\hline SO4-- & & & & & & & & & \\
\hline CO3-- & & & & & & & & & \\
\hline S-- & & & & & & & & & \\
\hline $\mathrm{OH}-$ & 100.00 & & & 100.00 & & & 100.00 & & \\
\hline HG2++ & & & & & & & & & \\
\hline N-HEX-01 & & & & & & & & & \\
\hline $\mathrm{CH} 4$ & & & & & & & & & \\
\hline $\mathrm{C} 2 \mathrm{H} 6$ & & & & & & & & & \\
\hline $\mathrm{C} 3 \mathrm{H} 8$ & & & & & & & & & \\
\hline NA3PO4 & & & & & & & & & \\
\hline NA3PO4(S & 0.00 & & & 0.88 & & & 0.97 & & \\
\hline K3PO4 & 0.00 & & & 0.88 & & & 0.97 & & \\
\hline ALPO4 & 0.00 & & & 0.88 & & & 0.97 & & \\
\hline PLUS1 & & & & & & & & & \\
\hline PLUS2 & & & & & & & & & \\
\hline PLUS3 & & & & & & & & & \\
\hline PLUS4 & 0.00 & & & 0.88 & & & 0.97 & & \\
\hline PLUS5 & 0.00 & & & 0.88 & & & 0.97 & & \\
\hline PLUS6 & 0.00 & & & 0.88 & & & 0.97 & & \\
\hline MINUS1 & & 8.72 & & & 0.12 & & & 0.12 & \\
\hline $\mathrm{CAOH}+$ & 99.97 & & & 99.97 & & & 99.97 & & \\
\hline $\mathrm{HGOH}+$ & & & & & & & & & \\
\hline
\end{tabular}




\begin{tabular}{|c|c|c|c|c|c|c|c|c|c|}
\hline \multirow[b]{3}{*}{ SPECIE } & \multicolumn{9}{|c|}{ PER CENT ABSOLUTE DEVIATION OF ENRTL FROM IDEAL ${ }^{\mathrm{a}}$} \\
\hline & \multicolumn{3}{|c|}{ MOLE OR MASS FLOW } & \multicolumn{3}{|c|}{ MOLE FRACTION } & \multicolumn{3}{|c|}{ MASS FRACTION } \\
\hline & $\begin{array}{l}\mathbf{P} \\
\mathbf{R} \\
\mathbf{O} \\
\mathbf{D} \\
\mathbf{U} \\
\mathbf{C} \\
\mathbf{T}\end{array}$ & $\begin{array}{l}\mathbf{H} \\
\mathbf{G} \\
- \\
\mathbf{G} \\
\mathbf{A} \\
\mathbf{C}\end{array}$ & $\begin{array}{l}\mathbf{S} \\
\mathbf{T} \\
\mathbf{A} \\
\mathbf{C} \\
\mathbf{K} \\
\mathbf{G} \\
\mathbf{A} \\
\mathbf{S} \\
\end{array}$ & $\begin{array}{l}\mathbf{P} \\
\mathbf{R} \\
\mathbf{O} \\
\mathbf{D} \\
\mathbf{U} \\
\mathbf{C} \\
\mathbf{T}\end{array}$ & $\begin{array}{l}\mathbf{H} \\
\mathbf{G} \\
- \\
\mathbf{G} \\
\mathbf{A} \\
\mathbf{C}\end{array}$ & $\begin{array}{l}\mathbf{S} \\
\mathbf{T} \\
\mathbf{A} \\
\mathbf{C} \\
\mathbf{K} \\
\mathbf{G} \\
\mathbf{A} \\
\mathbf{S} \\
\end{array}$ & $\begin{array}{l}\mathbf{P} \\
\mathbf{R} \\
\mathbf{O} \\
\mathbf{D} \\
\mathbf{U} \\
\mathbf{C} \\
\mathbf{T}\end{array}$ & $\begin{array}{l}\mathbf{H} \\
\mathbf{G} \\
- \\
\mathbf{G} \\
\mathbf{A} \\
\mathbf{C}\end{array}$ & $\begin{array}{l}\mathbf{S} \\
\mathbf{T} \\
\mathbf{A} \\
\mathbf{C} \\
\mathbf{K} \\
\mathbf{G} \\
\mathbf{A} \\
\mathbf{S} \\
\end{array}$ \\
\hline $\mathrm{HG}(\mathrm{OH}) 2$ & & & & & & & & & \\
\hline CASO4(S) & 0.00 & & & 0.88 & & & 0.97 & & \\
\hline CACL2(S) & & & & & & & & & \\
\hline $\mathrm{KOH}(\mathrm{S})$ & 0.00 & & & 0.88 & & & 0.97 & & \\
\hline $\mathrm{NAOH}(\mathrm{S})$ & 0.00 & & & 0.88 & & & 0.97 & & \\
\hline Maximum & 274.52 & 8.72 & 99.94 & 271.23 & 9.43 & 99.95 & 270.90 & 9.43 & 99.95 \\
\hline Minimum & 0.00 & 0.00 & 0.00 & 0.40 & 0.00 & 1.24 & 0.49 & 0.00 & 1.18 \\
\hline Average & 17.65 & 5.78 & 9.02 & 18.22 & 3.18 & 10.68 & 18.28 & 3.18 & 10.32 \\
\hline Std. Dev. & 48.44 & 5.01 & 26.34 & 47.81 & 5.41 & 25.89 & 47.74 & 5.41 & 25.99 \\
\hline
\end{tabular}

${ }^{\mathrm{a}}$ Blank cell indicates a zero concentration in a stream, which results in division by zero for the calculation of the $\%$ deviation. 